\title{
Multi-proxy approach detects heterogeneous habitats for primates during the Miocene climatic optimum in Central Europe
}

\author{
Gildas Merceron $^{\mathrm{a}, \mathrm{b}, *}$, Loïc Costeur ${ }^{\mathrm{c}}$, Olivier Maridet ${ }^{\mathrm{d}, \mathrm{e}}$, Anusha Ramdarshan ${ }^{\mathrm{f}}$, Ursula B. Göhlich ${ }^{\mathrm{e}, \star \star}$ \\ a Laboratoire de Géologie de Lyon, CNRS, ENS, Université Lyon-1 - Campus La Doua - Bat. Geode - 2, rue Raphael Dubois, 69622 Villeurbanne, France \\ b IPHEP (UMR 7262) CNRS \& Université de Poitiers, France \\ c Naturhistorisches Museum Basel, Augustinergasse 2, CH-4001 Basel, Switzerland \\ d Key Laboratory of Evolutionary Systematics of Vertebrates, Institute of Vertebrate Paleontology and Paleoanthropology, Chinese Academy of Sciences, Beijing, China \\ e Geologisch-paläontologische Abteilung, Naturhistorisches Museum Wien, 1010 Wien, Austria \\ f Institut des Sciences de l'Évolution UMR 5554, CNRS, Université Montpellier 2, France
}

Keywords:

Environments

Mammals

Ruminants

Cenograms

Temperatures

Microwear

\begin{abstract}
The present study attempts to characterize the environmental conditions that prevailed along the western shores of the Central Paratethys and its hinterland during the early middle Miocene at the same time $t$ primates reached their peak in species diversity in Central Europe. Based on faunal structure (using cenograms), paleotemperature reconstruction (using cricetid diversity), and dietary reconstruction of ruminants (using molar micro-wear analyses), four faunal assemblages are used to characterize the regional environmental context. The cenograms for Göriach and Devínska Novà Ves Zapfe's fissure site support the presence of mosaic environments with open areas under rather humid conditions. This is also supported by the dental micro-wear analyses of ruminants. The species of Palaeomerycidae were most probably the only predominant browsers. Surprisingly, the three cervids, Dicrocerus, Heteroprox, and Euprox, were highly involved in grazing. Pseudoeotragus seegrabensis was likely a generalist and the two specimens assigned to the second bovid, Eotragus clavatus, were browsers. The two species of tragulids plot between fruit browsers and generalists. Moreover, paleotemperatures based on cricetid diversity estimate mean annual temperature at about $18{ }^{\circ} \mathrm{C}$ with potential high seasonal variations. These data support the predominance of mosaic landscapes along the western shores of the Central Paratethys and its hinterland during the Miocene Climatic Optimum as primates reach a peak in species diversity. This result lends credence to the hypothesis that environmental heterogeneity favours radiation among mammals, and that the specific environmental context of the Central Paratethys western border might explain the high diversity of the middle Miocene primates.
\end{abstract}

\section{Introduction}

The Pannonian Basin in Europe was home to an important primate radiation during the early middle Miocene. Indeed, two superfamilies are known in the region during that time period, the Pliopithecoidea and the Hominoidea (Begun et al., 2006). Among the former, five taxa representing two families (Crouzelidae and Pliopithecidae) are known (Begun et al., 2006; Nargolwalla et al., 2006). Among the Hominoidea, two species are recognized: Griphopithecus suessi Abel, 1902 from Devínská Nová Ves - Sandberg in Slovakia and Klein Hadersdorf in Austria, and Dryopithecus fontani

\footnotetext{
* Corresponding author.

** Corresponding author.

E-mail addresses:

gildas.merceron@univ-lyon1.fr, gildas.merceron@univ-poitiers.fr (G. Merceron), ursula.goehlich@nhm-wien.ac.at (U.B. Göhlich).
}

Lartet, 1856 known from St. Stefan im Lavanttal in Austria (Begun et al., 2006). Similarly, artiodactyls, and especially Ruminantia, were also noticeably diversified with dozens of species representing several families, including, Bovidae, Cervidae, Tragulidae, Moschidae and Palaeomerycidae.

Our goal here is to characterize the environments of primates at a regional scale. The present investigation is focused on four middle Miocene Austrian (Göriach, Leoben, Eibiswald) and Slovak (Devínska Novà Ves Zapfe's fissures) localities (Table 1), two of which yield primate remains: Göriach and the Slovak locality (previously referred to as Neudorf an der March Zapfe's fissures; Fig. 1). Devínska Novà Ves Zapfe's fissure site is the type locality of Epipliopithecus vindobonensis Zapfe and Hürzeler, 1957. Göriach is the type locality for a second species belonging to the Pliopithecoidea, Pliopithecus platyodon Biederman, 1863. All four localities have also yielded many fossil ruminants, which will be analysed here. As 
Table 1

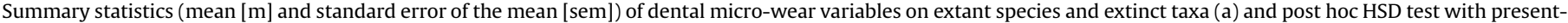
day and extinct ruminants (b).

\begin{tabular}{|c|c|c|c|c|c|c|c|c|c|c|c|c|c|c|c|}
\hline \multirow[t]{2}{*}{ (a) } & \multirow[t]{2}{*}{$\mathrm{N}$} & \multicolumn{2}{|c|}{ Ns* } & \multicolumn{2}{|c|}{$\mathrm{Np}$} & \multicolumn{2}{|c|}{$\mathrm{Pp}(\%)$} & \multicolumn{2}{|c|}{ Ls $(\mu \mathrm{m})$} & \multicolumn{2}{|c|}{ Nws } & \multicolumn{2}{|c|}{ Nlp } & \multicolumn{2}{|c|}{ Tot } \\
\hline & & $\mathrm{m}$ & sem & $\mathrm{m}$ & sem & $\mathrm{m}$ & sem & $\mathrm{m}$ & sem & $\mathrm{m}$ & sem & $\mathrm{m}$ & sem & $\mathrm{m}$ & sem \\
\hline Leaf browsers & 32 & 15.1 & 0.68 & 31.9 & 3.0 & 65.3 & 2.1 & 149.6 & 8.1 & 0.8 & 0.2 & 5.4 & 0.8 & 47.0 & 3.1 \\
\hline Leaf/fruit browsers & 195 & 21.0 & 0.47 & 32.4 & 0.9 & 59.3 & 0.8 & 131.3 & 2.5 & 1.1 & 0.1 & 5.3 & 0.2 & 53.4 & 1.1 \\
\hline Fruit browsers & 27 & 25.0 & 1.68 & 42.3 & 3.2 & 61.8 & 2.5 & 149.7 & 7.7 & 2.5 & 0.4 & 7.2 & 0.8 & 67.3 & 3.6 \\
\hline Generalists & 110 & 26.5 & 0.82 & 41.5 & 1.9 & 58.3 & 1.6 & 159.1 & 4.2 & 1.3 & 0.1 & 5.6 & 0.4 & 68.0 & 1.8 \\
\hline Grazers & 141 & 25.7 & 0.47 & 16.1 & 0.7 & 36.6 & 1.0 & 168.7 & 3.4 & 2.3 & 0.1 & 3.4 & 0.2 & 41.8 & 1.0 \\
\hline Dicroceros elegans & 19 & 31.3 & 1.61 & 23.2 & 3.0 & 46.4 & 3.9 & 202.7 & 10.7 & 4.2 & 0.7 & 3.5 & 0.9 & 61.3 & 3.1 \\
\hline Euprox minimus & 8 & 30.6 & 3.02 & 18.6 & 4.8 & 43.2 & 6.7 & 180.2 & 15.7 & 4.0 & 0.7 & 3.7 & 0.7 & 56.0 & 3.5 \\
\hline Heteroprox larteti & 5 & 32.8 & 4.76 & 22.8 & 4.2 & 42.1 & 7.8 & 177.7 & 8.2 & 4.4 & 0.6 & 5.0 & 1.4 & 56.4 & 2.1 \\
\hline Dorcatherium crassum & 12 & 31.7 & 1.21 & 28.6 & 4.1 & 48.9 & 4.0 & 169.1 & 7.9 & 3.0 & 0.5 & 6.2 & 0.9 & 65.5 & 5.1 \\
\hline D. vindebonense & 13 & 28.5 & 2.72 & 25.5 & 4.3 & 47.7 & 6.0 & 183.4 & 16.7 & 3.6 & 0.5 & 5.3 & 1.5 & 59.5 & 6.1 \\
\hline Eotragus clavatus & 2 & 18.5 & 0.50 & 37.5 & 4.5 & 72.3 & 3.0 & 184.7 & 50.2 & 1.0 & 1.0 & 6.0 & 2.0 & 67.5 & 5.5 \\
\hline Pseudoeotragus seegrabensis & 26 & 28.2 & 1.39 & 32.2 & 3.3 & 50.7 & 3.1 & 164.5 & 6.8 & 3.6 & 0.5 & 5.0 & 0.6 & 60.4 & 2.8 \\
\hline Ampelomeryx major & 2 & 18.5 & 1.50 & 19.8 & 16.8 & 52.0 & 21.0 & 198.5 & 4.0 & 4.0 & 2.0 & 1.0 & 1.0 & 46.0 & 17.0 \\
\hline Palaeomeryx kaupi & 5 & 23.8 & 2.46 & 27.6 & 7.8 & 49.5 & 9.6 & 186.8 & 19.8 & 2.4 & 0.9 & 5.0 & 1.9 & 51.4 & 6.1 \\
\hline P. elegans & 1 & 26.0 & & 11.5 & & 40.9 & & 154.8 & & 5.0 & & 3.0 & & 44.0 & \\
\hline (b) & & \multicolumn{3}{|c|}{ Leaf browsers } & \multicolumn{3}{|c|}{ Leaf/fruit browsers } & \multicolumn{3}{|c|}{ Fruit browsers } & \multicolumn{3}{|c|}{ Generalists } & \multicolumn{2}{|c|}{ Grazers } \\
\hline Dicroceros elegans & & \multicolumn{3}{|c|}{ Pp, Ns, Ls, Tot, Nws } & \multicolumn{3}{|c|}{ Pp, Ns, Ls, Nws } & \multicolumn{3}{|c|}{ Pp, Np, Ls, Nlp } & \multicolumn{3}{|c|}{ Np, Ls, Nws } & \multicolumn{2}{|c|}{ Tot } \\
\hline Euprox minimus & & \multicolumn{3}{|c|}{ Pp, Ns, Nws } & \multicolumn{3}{|c|}{ Ns, Ls, Nws } & \multicolumn{3}{|c|}{$\mathrm{Np}$} & \multicolumn{3}{|c|}{ Np, Nws } & \multicolumn{2}{|l|}{$\varnothing$} \\
\hline Heteroprox larteti & & \multicolumn{3}{|c|}{ Pp, Ns, Nws } & \multicolumn{3}{|c|}{ Nws } & \multicolumn{3}{|c|}{$\varnothing$} & & & & $\varnothing$ & \\
\hline Dorcatherium crassum & & $\mathrm{Pp}, \mathrm{Ns}$, & ws, Tot & & & , Nws & & $\ell$ & & & & & & $\mathrm{Np}$, & , Tot \\
\hline D. vindebonense & & Pp, Ns, & & & & , Nws & & $\mathrm{N}$ & & & & Nws & & Tot & \\
\hline Eotragus clavatus & & $\varnothing$ & & & $\varnothing$ & & & $\varnothing$ & & & & & & $\mathrm{Pp}$ & \\
\hline Pseudoeotragus seegrabensis & & $\mathrm{Pp}, \mathrm{Ns}$, & t, Nws & & & , Ls, N & & $\varnothing$ & & & & & & $\mathrm{Pp}$, & Tot \\
\hline Ampelomeryx major & & $\varnothing$ & & & $\varnothing$ & & & $\varnothing$ & & & & & & $\varnothing$ & \\
\hline Palaeomeryx kaupi & & $\varnothing$ & & & $\varnothing$ & & & $\ell$ & & & & & & $\varnothing$ & \\
\hline P. elegans & & $\varnothing$ & & & $\varnothing$ & & & $\widehat{\ell}$ & & & & & & $\varnothing$ & \\
\hline
\end{tabular}

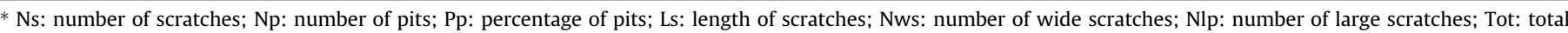
number of micro-wear scars. See Appendices A-C for material and ANOVA details.

ruminants are the most diverse and abundant large mammals during the Neogene in Europe, they are the focus of a dental microwear analysis with the view of investigating paleoenvironments and ecological partitioning. Structural faunal analysis using cenograms for both Göriach and Devínska Novà Ves will complete the study. Additionally, analysis of cricetid rodent diversity, a method for estimating paleotemperatures established by Legendre et al. (2005), is also applied to Devínska Novà Ves whose small mammal assemblage is sufficiently diversified.

Together, diet reconstruction, cenograms, and paleotemperature estimation provide the opportunity to depict regional environments and will complement previous research (Ivanov et al., 2007) on the vegetation that grew in these environments and its climatic context. Ivanov et al. (2007) stated that the northern and southwestern Central Paratethys shores were covered with thermophilous plant taxa indicating a warm subtropical to warm temperate humid climate. In this context, the presence of a large body of water such as the Central Paratethys is thought to be a source of moisture, which might have played a major role in shaping regional and local environments.

\section{Material and methods}

\section{Localities}

Four mammalian faunas are considered in this analysis. They belong to middle Miocene localities from Austria and Slovakia, representing two different depositional environments. Devínska Nová Ves (Slovakia, Vienna Basin) and Eibiswald (Austria, Styrian Basin) are situated along the western shore of the Central Paratethys, while Leoben and Göriach (both Austrian) represent two lacustrine systems in two intramontane basins (Leoben Basin and

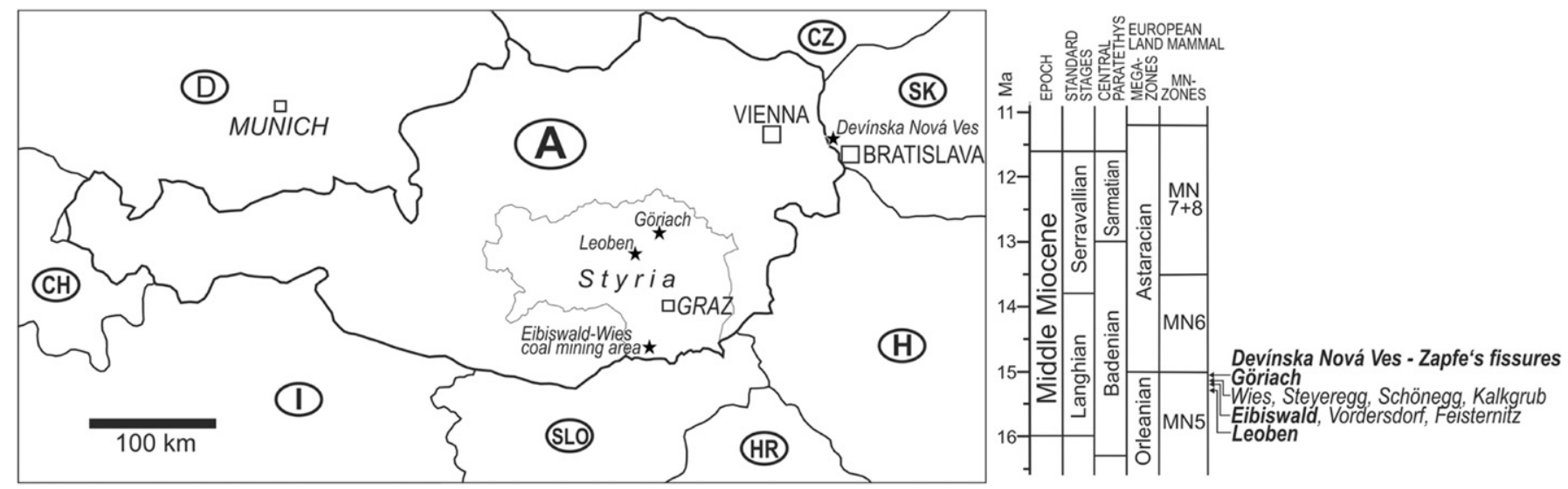

Figure 1. Geographic and stratigraphic position of the considered middle Miocene localities. 
Aflenz Basin), about $50 \mathrm{~km}$ west of the shore but unconnected to the Central Paratethys (Sachsenhofer et al., 2003). The Austrian sample includes ruminants from Göriach, Leoben and Eibiswald (Fig. 1). Many other Badenian localities (Vordersdorf, Feisternitz, Wies, Schönegg, Steyregg and Kalkgrub) of the Styrian Basin have also yielded mammal remains, but too few, and are consequently not included in the present study. They are correlated to MN5 (biochronological zone of the European Neogene Mammal scale) and their age is estimated at about $15 \mathrm{Ma}$ (millions of years ago) (Gross et al., 2007).

The Göriach locality was supposed to represent the Mammal Neogene unit MN6, but more recently it was placed in late MN5, close to the MN5-6 transition (Daxner-Höck et al., 2004; Made et al., 2007). The Göriach locality, which is situated in the intramontane Aflenz basin, yielded the richest Badenian vertebrate fauna of Styria. For a compilation of the vertebrate fauna, see Hofmann (1893), Mottl (1970), and Gross (2002).

The Eibiswald locality belongs to the 'Wies-Eibiswald' coalmining district (Styria, Austria) in the Styrian Neogene Basin, which is the westernmost sub-basin of the Pannonian Basin. Two main coal seams ('Eibiswald/Vordersdorf' coal seam and 'Wies' coal seam) have yielded many vertebrate fossils. The 'Eibiswald/Vordersdorf' coal seam includes the Eibiswald localities but also Feisternitz and Vordersdorf, two contemporaneous localities with fossil material that is not included in this study. This coal seam represents low-lying freshwater mire in a limnic-deltaic environment (Gross and Martin, 2008). Recent radiometric dating of tuffaceous layers just above the 'Eibiswald/Vordersdorf' coal seam (Handler et al., 2006) resulted in an age of $15.22(+/-0.17)$ Ma (early Badenian, MN5). For more details on the lithostratigraphy, the chronostratigraphic correlation of the deposits of the 'Wies-Eibiswald' coalmining district, and its vertebrate fauna, see Mottl (1970), Gross (2002), Gross and Martin (2008).

The fossil vertebrate fauna from Leoben, with its two sites Leoben-Seegraben and Leoben-Münzenberg, situated in the intramonane Leoben Basin, was also discovered during the coal-mining period. The vertebrate fauna of Leoben-Seegraben was formerly interpreted as belonging to MN6, but following Made (1997) and Made et al. (2007), has to be placed in MN5. A compilation of the fauna is given by Hofmann and Zdarsky (1905) and Mottl (1970).

The Slovak locality of Devínska Novà Ves Zapfe's fissure, formerly called 'Neudorf an der March' or only 'Neudorf' Zapfe's fissure, a suburban part of Bratislava, is situated on the northeast margin of the Vienna Basin (Fig. 1). The different localities in this area are of different ages. Devínska Novà Ves Zapfe's fissure site is of Badenian age and correlated to MN5. Its age is considered to be close to the previously mentioned Austrian localities (Fig. 1). Devínska Nová Ves Zapfe's fissure site has yielded the primate remains of $E$. vindobonensis. The most recent data about this locality and its vertebrate fauna were given by Sabol and Holec (2002) and Begun et al. (2006).

\section{Investigated taxa for dental micro-wear analyses}

The species analysed here do not represent all of the ruminants known in all of these localities. Indeed, here are included only the taxa for which teeth were preserved well enough to perform dental micro-wear analysis: two bovids, Eotragus clavatus Gervais, 1850 (sensu Made, in press) and Pseudoeotragus seegrabensis Made, 1989 (Bovidae), Dicrocerus elegans Lartet, 1837, Euprox minimus Toula, 1884, and Heteroprox larteti Filhol, 1891 (Cervidae), Dorcatherium crassum Lartet, 1851, Dorcatherium vindebonense von Meyer, 1846 (Tragulidae), Ampelomeryx magnus Lartet, 1851, Palaeomeryx kaupi von Meyer, 1834, Palaeomeryx eminens von Meyer, 1847 (Palaeomerycidae; Table 1; Appendix A; Duranthon et al., 1995; Rössner, 2010a, b; Astibia, in press). The fossil material considered for the dental micro-wear analyses is housed in the Naturhistorisches Museum Wien (NHMW), the Palaeontological Institute of the University of Vienna (PIUW), and the Landesmuseum Joanneum Graz (LMJ).

\section{Comparative datasets of extant species}

Here we select extant species of ruminants with which the investigated species share selenodonty. We focus on 505 wild-shot individuals of 23 present-day species of ruminant, representing the leaf-dominated browsers, fruit-dominated browsers, browsers foraging both on fruits and foliages, generalists and grazers (Table 1 and Appendix A).

\section{Investigated teeth and dental facets}

The study is focused on the second lower and upper molars of extant species. For fossils, the sample is widened by including first and third molars in the study. The paracone lingual enamel facets and the protoconid buccal enamel facets are both considered for this analysis (Fig. 2). These dental facets share a similar dental microwear pattern because both occlude during the chewing-shearing phase. Accordingly, data from lower and upper molars are combined in a single sample (Teaford and Walker, 1984; Janis, 1990).

\section{Molding and casting procedures}

The molds were made with a polyvinylsiloxane material polymerized by addition reaction (Regular Body Microsystem, Coltene President), and were prepared in a formwork (Putty soft, Coltene President) (Merceron et al., 2005). The mold reproduces only the shearing facets that we are interested in. The negative replicas of the dental facet were then placed horizontally in the formwork. In this way, the thickness of transparent resin underneath dental facet positive replicas is almost constant throughout the cast so lighting conditions (intensity and contrast) are homogeneous throughout the image field. Such a procedure is the only way to get sharp and contrasted images using light stereomicroscopy (Fig. 2) (Merceron et al., 2004b, 2005). Once the transparent polyurethane resin has been poured (Ebalta MG709/20), the molds are not put in a vacuum bell jar (Merceron et al., 2005) or a centrifugal machine (Ungar, 1996), but instead are directly placed in a autoclave with the temperature set at about $50{ }^{\circ} \mathrm{C}$ and pressure at $2 \times 10^{5} \mathrm{~Pa}$ for $5 \mathrm{~h}$. After cooling down, the autoclave is depressurized and eventually opens. The use of an autoclave allows us to obtain casts without any bubbles on either the cast surface or within the cast itself.

\section{Image capture and analysis}

The protocol of Merceron et al. (2005) is followed here (see also Merceron et al., 2007a; Calandra et al., 2008; Gomes Rodrigues et al., 2009; Ramdarshan et al., 2010). The dental facets were processed by digitizing ( $1 \mu \mathrm{m}=1$ pixel) at 256 Gy levels with a magnification at $\times 30$, using a CCD camera (with $a \times 0.5$ lens Leica ICD, Leica Microsystems ${ }^{\circledR}$ ) connected to a light stereomicroscope $\left(\times 60\right.$ on a Leica MZ 125, Leica Microsystems $\left.{ }^{\circledR}\right)$. The main issue at that point is not the rate of magnification but resolution. Each photograph is magnified up to $120 \times$ for working on a computer monitor. A $0.09 \mathrm{~mm}^{2}$-square is delimited about halfway up the enamel facet. Image analysis was not conducted with Optimas (Merceron et al., 2005), but with ImageJ (Abramoff et al., 2004) and the plug-in ObjectJ (Vischer et al., 1994). This provides the same set of tools as Optimas. Data were collected by one of us (GM). Within this standardized square, each micro-wear scar was quantified as 

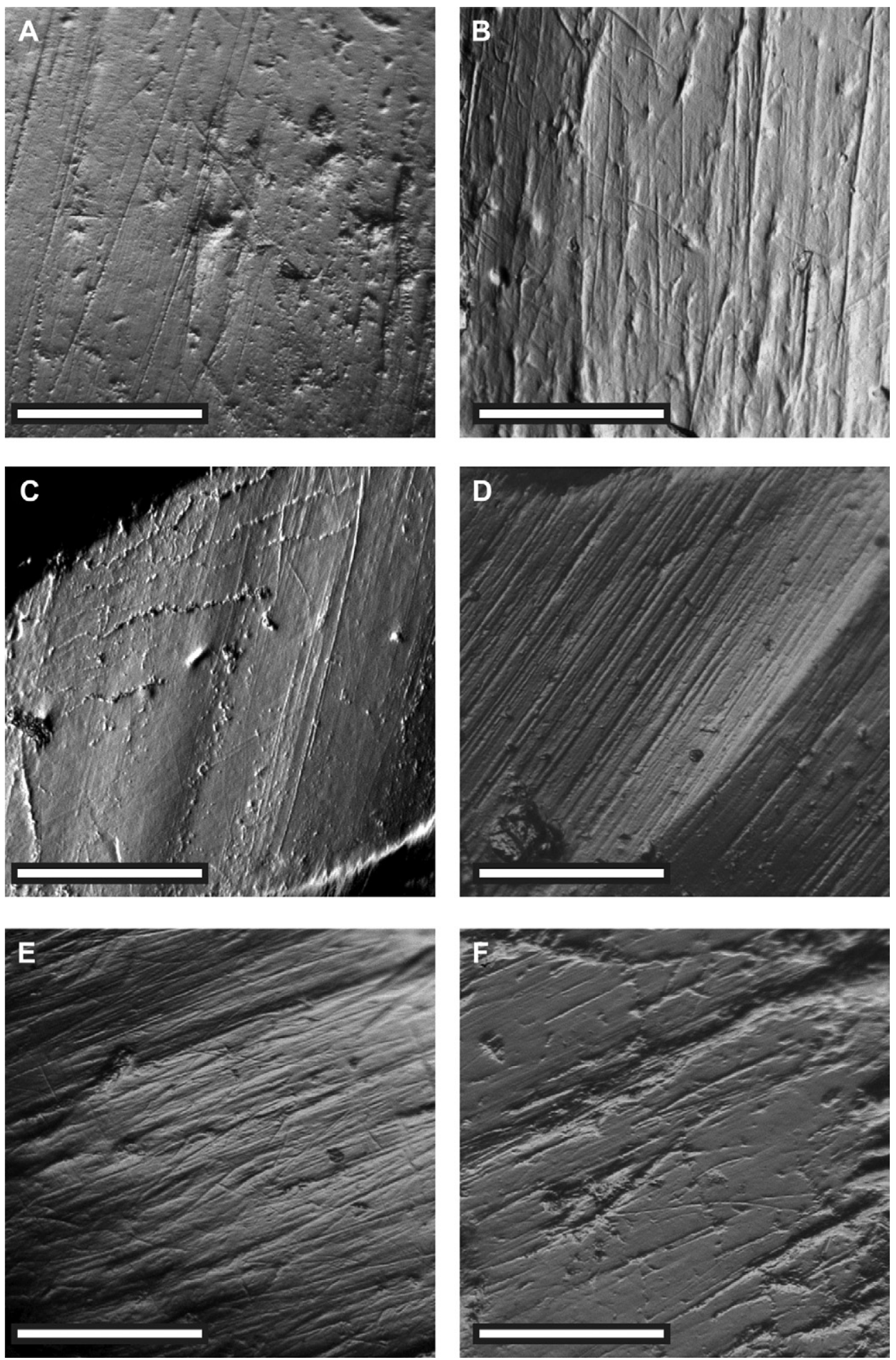

Figure 2. Light stereomicrographs showing the dental micro-wear pattern on the molar shearing facets of Dicroceros elegans from Göriach (A; LMJ 57497), Dorcatherium vindebonensis from Leoben (B; LMJ 3802), Eotragus clavatus from Göriach (C; LMJ 1537), Euprox minimus from Göriach (D; LMJ 4026), Heteroprox larteti from Leoben (E; LMJ 3786), and Palaeomeryx eminens from Göriach (F; LMJ 3777). Scale bar $=300 \mu \mathrm{m}$.

a pit or a scratch. Pits are clearly distinguishable from scratches. However, the distinction between elongated pits and short wide scratches may be unreliable. Microwear scars are then defined as pits or scratches as follows: pits have a width to length ratio greater than one-quarter, and scratches have a lower ratio (Grine, 1986). Also, the micro-wear scars are measured and then assigned to a category depending on their size (length of major axis for pits and width for scratches). Subsequently, the numbers of wide scratches (Nws; width $>15 \mu \mathrm{m}$ ) and large pits (Nlp; major axis $>15 \mu \mathrm{m}$ ) are determined. The total number of micro-wear scars (Tot $=\mathrm{Np}+\mathrm{Ns}$ ) and the percentage of pits $(\mathrm{Pp}=100 \times \mathrm{Np} / \mathrm{Tot})$ are then computed (Merceron et al., 2004b, 2005). 
Variables

All recent papers clearly support that the three main variables (number of scratches, number of pits, percentage of pits) discriminate the basic dietary categories (Solounias et al., 1988; Solounias and Semprebon, 2002; Merceron et al., 2007a, b). The percentage of pits (Pp) is known to significantly differentiate grazers and browsers, the latter having high values (from about 60\% to $80 \%$ ). Among browsers, scratch density discriminates leaf-dominated versus fruit-dominated browsers (Solounias and Semprebon, 2002; Merceron et al., 2007a, b), the latter having more scratches. Other browsing species like Capreolus capreolus forage for foliage and fruit in a more balanced proportion. Grazers such as Kobus kob tend to have percentages of pits below $40 \%$. Generalists such as Cervus elaphus plot between grazers and browsers. Seasonal/ regional mixed feeders share affinities with either grazers or browsers (Solounias and Semprebon, 2002). This bimodal distribution observed for seasonal mixed feeders actually reflects a strong seasonal switch from browsing to grazing (Walker et al., 1978). Such strong seasonal changes in grass/browse proportion are not seen among generalists, also named 'meal by meal' mixed feeders (Solounias and Semprebon, 2002; Merceron et al., 2007a, b), since generalists browse and graze on a year-round basis. The number of pits also provides information on the proportion of hard and brittle elements such as grit or hard seeds (Merceron et al., 2004a). Other variables are also included in this study, such as number of wide scratches (Nws), large pits (Nlp) and also the length of scratches (Ls). The occurrence of wide scratches may have multiple sources, including the consumption of fruits, or ligneous or semi-ligneous twigs. Furthermore the occurrence of large pits seems to be controlled by the ingestion of seeds or exogenous elements. For most species, the consumption of fruits and seeds is seasonal, meaning that such behaviour is only known over a limited amount of time within a year. However, because of the sample heterogeneity (in tooth, sample size, sites) and the day-base to month-base short turnover in micro-wear formations (Teaford and Oyen, 1989; Teaford and Robinson, 1989; Merceron et al., 2010), we will focus on three major variables rather than on minor ones for which no one can objectively attribute the underlying causes and are at best useless, or at worst a source of misinterpretation.

\section{Statistics}

Data were then analysed with the software Statistica (StatSoft). Statistical analyses were applied to highlight potential inter-group differences in dental micro-wear patterns. As the conditions for using parametric tests were not fulfilled (i.e., normality), the data were rank transformed before analysis (Conover and Iman, 1981). A single classification ANOVA will investigate differences in dental micro-wear patterns between extant and extinct taxa. Individual ANOVAs coupled with Tukey's Honest Significant Difference (HSD) multi-comparison tests were used to pinpoint sources of significant variation. Different sets of ANOVAs are run in order to investigate dental micro-wear patterns.

\section{Faunal structure analysis}

A cenogram analysis was conducted for the localities of Göriach and Devínska Novà Ves Zapfe's fissure site, which yielded enough species to interpret a community-based body mass distribution (Fig. 3). This method has been successfully applied to various Cenozoic localities across the world to infer paleoenvironments. It has been used on Old World faunas (Legendre, 1986, 1989; de Bonis et al., 1992; Montuire et al., 1997; Costeur, 2005a, b; Costeur and Legendre, 2008; Deng, 2009), but also on endemic faunas from South America (Croft,

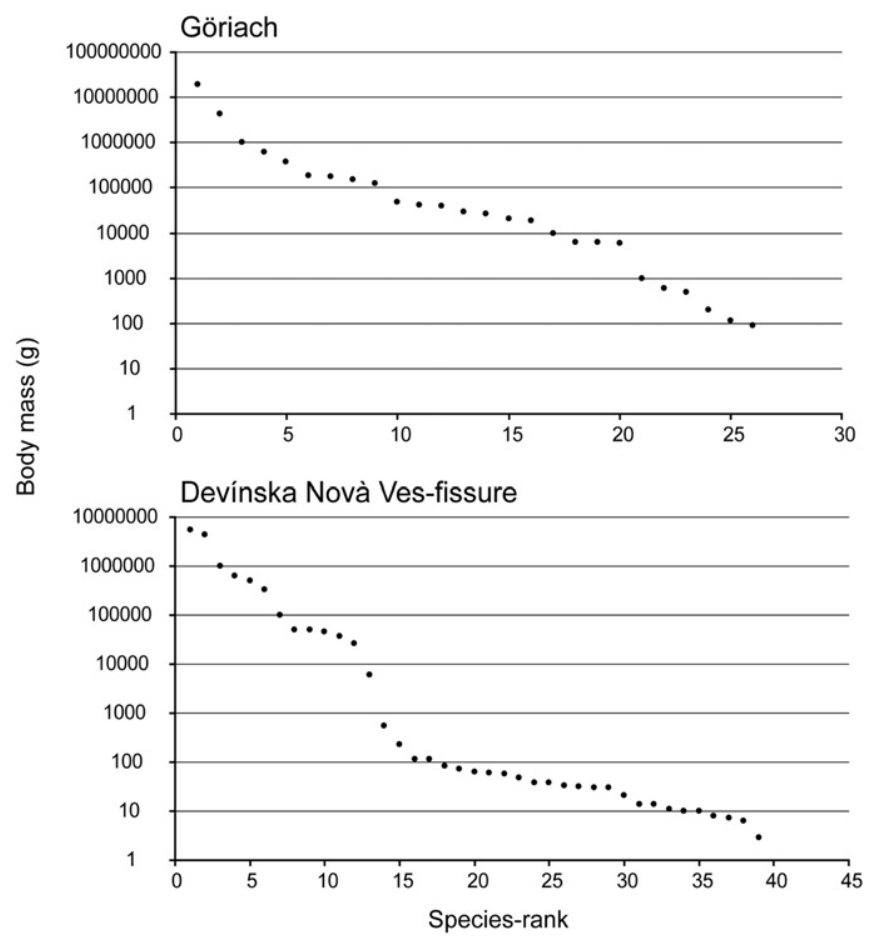

Figure 3. Cenogram profiles for the mammalian community of Göriach compared with the one for the Devínska Novà Ves fissure sites.

2001) and Australia (Travouillon and Legendre, 2009). Several of the above mentioned papers describe the method in detail, including how body masses are inferred from teeth measurements. Individual body mass is a fundamental biological and ecological parameter, and participates in structuring mammalian communities. As such, rankordered body mass distributions of the individual species that constitute a community, known as cenograms, give much insight into community structure but also into the environment inhabited by the community (Legendre, 1986,1989). Teeth measurements were mostly taken from the literature except for some species measured by one of us (LC) in the collections of the Natural History Museum Basel (see Appendix D). The equations used to reconstruct body masses from the lower first molars are from Legendre (Legendre, 1989). As explained in detail in Costeur and Legendre (2008), we compare the 'large' and 'small' mammal segments of the cenogram (large and small are used here to ease understanding), with an experimental limit of $8 \mathrm{~kg}$ ('large mammals' above, 'small mammals' below), which has been proven to be an efficient cenogram parameter. This $8 \mathrm{~kg}$-gap in body mass seems indeed to be correlated to mean annual precipitation (MAP) levels (Costeur and Legendre, 2008), which are good indirect indicators for vegetation density; the smaller the $8 \mathrm{~kg}$-gap, the higher the MAP. Costeur and Legendre (Costeur and Legendre, 2008) found a significant relationship between the sizes of the large versus small sizes gap at $8 \mathrm{~kg}$ (computed in log difference) $(r=-0.67, p<0.001)$ that indicates that MAP explains almost half of variation in gap size. This computation was performed on a database of 214 extant faunas distributed around the world and coming from an original data acquisition made by Legendre (1989). Other authors also showed significant relationships, although low but obtained on smaller datasets, between gaps at mid sizes in communities and vegetation structure (here approached with MAP) (Rodriguez, 1999). Legendre et al. (1991) did test other cenogram parameters (gaps at other limits (e.g., $500 \mathrm{~g}$ ), slopes of various segments such as the 1-100 g segment among others) against temperatures and precipitations but despite several significant relationships, none had a predictive power. 


\section{Paleotemperature reconstructions}

Here, we use a method established by Legendre et al. (2005), and summarized below. This method was already applied to the European Neogene and has proven to be reliable for estimating paleotemperatures within a period spanning the late early, middle, to early late Miocene (Legendre et al., 2005; Montuire et al., 2006; Costeur et al., 2007, in press). As demonstrated by Legendre et al. (2005), a relationship exists between extant New World cricetid species richness (independent variable) and the mean annual temperatures of their living environment (dependant variable), and extant New World cricetids can be used as ecological analogues for Neogene Old World cricetid rodents. Indeed, unlike Eurasian fossil cricetids, which were widely distributed and diversified, presentday cricetids are confined to Eurasia, living in steppic environments (Musser and Carleton, 1993) and their diversity, with only seven genera, is relatively low compared with the numerous genera known from the Neogene fossil record of Eurasia. In contrast, New World cricetids (mainly the subfamily Sigmodontinae), are represented by around 100 genera in North, Central and South America (Musser and Carleton, 1993). Dental morphologies within extant New World cricetids are also very close to those observed in Neogene European cricetids (Schaub, 1925; Stehlin and Schaub, 1951) in accordance to their close phylogenetic relationship (Jacobs and Lindsay, 1984; Slaughter and Ubelaker, 1984). Furthermore, the body size range of both groups is also very similar (Silva and Downing, 1995). The similarity between European fossil cricetids and American modern cricetids led Legendre et al. (2005) to propose a model using the New World subfamily as an ecological analogue for European fossil cricetids. Legendre et al. (2005) constructed a database of 282 extant local faunas, which yielded cricetid species roughly ranging from $70^{\circ}$ of latitude north to $-70^{\circ}$ of latitude south on the American continent. Legendre et al. (2005) observed that the species richness of New World cricetids varies greatly depending on the climatic context, for instance the localities from the coldest environments (such as in Alaska or northern Canada) do not sustain more than three species whereas tropical localities (such as in Venezuela, Bolivia, Paraguay or northern Brazil) sustain often more than ten species, up to 20 species in the richest localities. Based on climatic parameters and the faunal list of each locality, Legendre et al. (2005) established that local species richness is strongly correlated to local temperature parameters: mean annual temperature (MAT; $r^{2}=0.882$ ), mean daily temperature of the coldest month $\left(r^{2}=0.835\right)$, and mean daily temperature of the warmest month $\left(r^{2}=0.643\right)$. These correlations are applied to local fossil cricetid species richness in order to estimate paleotemperatures (Legendre et al., 2005; Montuire et al., 2006; Costeur et al., 2007 , in press). In contrast, the relationship between-species richness and precipitation is low $\left(r^{2}=0.193\right.$ for mean annual precipitation) and cannot be used for estimates in the fossil record.

\section{Results}

\section{Dental micro-wear patterns}

The first set of analyses on between-species differences in dental micro-wear patterns detects significant differences for all variables (Table 1; Appendix C). The subsequent post hoc tests track the source of variations (Table 1 ).

The three cervids, $D$. elegans, $H$. larteti, and E. minimus, differ in many variables (especially in Ns, Pp, and Nws) from leaf-dominated and fruit-leaf browsers. They also differ from fruit-dominated browsers in having fewer pits (with the exception of $H$. larteti) and from generalists in having fewer pits and wider scratches. These three cervids do not differ from present-day grazers with the exception of $D$. elegans, which has significantly more micro-wear scars than grazers.

The two traguilds, $D$. crassum and $D$. vindebonense, also differ from leaf-dominated and leaf/fruit browsers in having more intensively scratched molar shearing facets. $D$. vindobonense differs from fruit-dominated browsers and generalists in having fewer pits. D. vindobonense has more micro-wear scars on molar shearing facets than grazers. $D$. crassum has more pits, more large pits and more micro-wear scars than grazing ruminants. The two tragulids share with fruit-dominated browsers a high number of wide scratches, significantly higher than the ones found for generalists.

The sample for the first bovid, E. clavatus, is composed of two individuals from Göriach, so the results should be considered with caution. The only significant difference concerns the percentage of pits, which is higher than that of extant grazers. The percentage of pits, the numbers of scratches and pits of E. clavatus all together suggest that these two individuals likely browsed on leaves. The second bovid, $P$. seegrabensis, differs from leaf-dominated and leaf/ fruit browsers in having a lower pit percentage, more scratches and more wide ones. This antelope also differs from grazing ruminants in having more pits and consequently more micro-wear scars and higher pit percentage. $P$. seegrabensis also differs from generalists in having wider scratches.

None of the differences between the Palaeomerycidae and extant species clustered in dietary categories are highlighted as significant through the HSD test. However, one could note a low amount of micro-wear scars (Tot), a low amount of pits compared with other extinct ruminants, and few scratches especially for Ampelomeryx magnum and P. kaupi. All together, these data exclude grazing or fully frugivorous habits for the Palaemeryicidae and instead suggest leaf-dominated or leaf/fruit browsing habits. However, it is worth noting that the dental micro-wear patterns of $P$. eminens contrast with the patterns of the other species of Palaeomerycidae in having lower pit percentage. However, the small sample size $(n=1)$ prevents us from being definitive.

\section{Cenograms and paleotemperatures}

The fauna of Göriach is composed of 26 species of non-flying potential prey mammals. In addition, one bat and 13 carnivores are also known (Appendix D). The cenogram is biased and most probably does not reflect the exact amount of phytophagous and insectivorous species that were present. However, the high number of large species ( 17 species above $8 \mathrm{~kg}$ ) and the gap at mid-sizes are interesting enough to give paleoenvironmental interpretations (Fig. 3). The cenogram is typical for a fauna living in rather humid conditions. It shows a continuous and shallow slope in large species together with a very small gap at mid-sizes $(0.20$, corresponding to the difference in natural logarithm $(\log )$ between the lightest body size $>8 \mathrm{~kg}$ and the heaviest body size $<8 \mathrm{~kg}$ ). A closed environment seems to have prevailed even though biases in body mass distribution (probably too few small mammals were sampled) prevent any firm conclusion on this point. Likewise, due to the scarcity of small mammals in Göriach, we made the choice not to estimate paleotemperatures based on cricetid species richness for this locality.

The fauna of Devínska Novà Ves Zapfe's fissure site is more complete than that of Göriach and is composed of 40 herbivorous and insectivorous species (Appendix D). The cenogram is typical of rather humid conditions in a mosaic context of closed and more open areas. Indeed, the large number of small species (under $500 \mathrm{~g}$ ) indicates humid conditions. The middle-size gap is not very high ( 0.65 in $\log$ difference at $8 \mathrm{~kg}$ or 1.00 in $\log$ difference at $5 \mathrm{~kg}$ ) but only the presence of the arboreal primate Epipliopithecus vindoboniensis bridges a larger gap at mid-sizes that would otherwise be 
typical of open conditions (Fig. 3). This duality is also found in the components of the fauna since several species adapted to forest and humid conditions cohabit with a number of open landscape adapted species.

As opposed to Göriach, Devínska Novà Ves Zapfe's fissure site yielded a diversified assemblage of small mammals (27 species, including 17 rodents, see Appendix D). Among rodents, seven species of cricetid have been identified in the locality, including Anomalomys gaudryi, Democricetodon vindobonensis, Eumyarion latior, Eumyarion weinfurteri, Megacricetodon gregarious, Megacricetodon schaubi and Neocometes brunonis. Other well-known (and extensively sampled) European early middle Miocene localities have yielded a similar number of cricetids, including e.g., Sansan (France, six species) (Maridet and Sen, in press), CD24 (France, seven species) (Mein and Ginsburg, 2002), Zeglingen (Switzerland, six species) (Kälin, 1993), and Gisseltshausen (Germany, six species) (Heissig, 1989). Paleotemperature reconstructions based on cricetid species richness yield a mean annual temperature of $17.8^{\circ} \mathrm{C}$ (standard error between 14.6 and 21.0) and mean temperatures for the coldest month of $10.3^{\circ} \mathrm{C}\left(4.5^{\circ}-16.3^{\circ}\right)$ and warmest month of $24.8^{\circ} \mathrm{C}\left(21.8-27.9^{\circ} \mathrm{C}\right)$.

\section{Discussion}

\section{Regional scale environmental signals}

All of the localities investigated here allow us to describe the environment of the five primate species that coexisted in this region. The localities are dated to the middle Miocene, right in the Miocene Climatic Optimum, a period (ca. 17-14.7 Ma) characterized by a warm climate worldwide (Böhme, 2003; You et al., 2009). Böhme et al. (2011) and Bruch et al. (2011) identified a wetter climate than present in eastern and Central Europe. The model proposed by Eronen and Rook (2004) supports this and concludes that precipitation was higher than $1400 \mathrm{~mm} / \mathrm{year}$ in Central Europe during the middle Miocene. A strong latitudinal precipitation gradient settled over Europe with wetter areas in the north and east (Böhme, 2004; Costeur and Legendre, 2008). The cenograms for Göriach and Devínska Novà Ves fit well with this scenario with body size distributions typical of rather humid conditions. Furthermore, paleotemperatures calculated for Devínska Novà Ves Zapfe's fissures based on cricetid diversity are in very good agreement with estimates made from plant assemblages: MAT of $17.8^{\circ} \mathrm{C}$ with cricetids, and of $15.0^{\circ}-18.0^{\circ} \mathrm{C}$ with plants (Ivanov et al., 2002, 2007, 2011). Mean coldest and warmest month temperatures are also in the same range. The difference between the estimated mean annual temperatures of the warmest and coldest months is in the order of $14.0^{\circ} \mathrm{C}$, which indicates a strong seasonality. These temperatures, in association with the rather humid conditions deduced from the cenogram analysis, suggest a subtropical humid climate somewhat similar to the extant climate of south-eastern China (south of Shanghai), also characterised by a noticeable seasonality between winter and summer temperatures.

Although several studies analysed fossil records of the middle Miocene Paratethys area (Rössner, 2005, 2006, 2010a, b; Kaiser and Rössner, 2007), the impact of the Paratethys Sea on regional climates seems difficult to assess. The presence of large bodies of water is known to be a source of moisture and this could have played a major role for climates from a local to regional scale. The north- and south-western shores of the Central Paratethys and its close hinterland were covered with thermophilous plant taxa indicating a warm subtropical to warm temperate humid climate (Ivanov et al., 2011), while the flora of Devínska Novà Ves-Sandberg indicates a humid subtropical climate (Berger, 1951 in; Zapfe, 1960). Indeed, the presence of fossils of the plant genus Celtis (hackberry) at Devínska Novà Ves fissure site points to a warm temperate climate (Berger, 1951 in
Zapfe, 1960), but no other plant fossils were found, preventing any further conclusion for the locality itself. Badenian mean annual temperatures were high (Ivanov et al., 2002, 2011; and this study) and accordingly fit well in the context of the Miocene Climatic Optimum. The same studies on plants indicate the development of more open landscapes in the region towards the end of the middle Miocene (ca. 13-12 Ma). Our analysis tends to show the presence of mosaic environments with open areas already around at $15 \mathrm{Ma}$ on the western shores of the Central Paratethys and its nearby hinterland $(<100 \mathrm{~km})$. Kern et al. (2011) analysed the late Burdigalian flora of Stetten (Lower Austria) a locality that also yielded a fauna dated to MN5 (although a little younger than the Badenian faunas we are working on), and confirmed the presence of a warm subtropical climate.

\section{Feeding ecology of middle Miocene ruminants from Central Europe}

The diversity of feeding habits amongst ruminants from grazing to leaf-dominated browsing clearly supports recent studies on middle Miocene ruminants of western Europe. In most previous studies, brachyodont ruminants were depicted as forest dwellers and consequently browsers whereas our present study clearly highlights a more complex scheme.

The three cervids, D. elegans, E. minimus and $H$. larteti, were highly involved in grazing. DeMiguel et al. (2011) reach the same conclusion about species of Heteroprox and Euprox from the middle Miocene of Spain. These authors also found that mixed feeding habits including both grazing and browsing were known also for Procervulus since the early Miocene (DeMiguel et al., 2008, 2010). Such diets rich in grasses are also known for present-day cervids. For instance, the red deer in Europe or the barking deer in Asia may include up to $50 \%$ of grasses in their diet. This proportion can be even higher. In Nepal during dry seasons, tall grasses in alluvial flood plain make up $65 \%$ and $75 \%$ of the diet of the sympatric species, Cervus duvauceli and Axis porcinus, respectively (Wegge et al., 2006). The Tragulidae are represented here by two species of Dorcatherium. $D$. vindobonense plots with generalists, such as the red deer, whereas the sample of $D$. crassum may have been more engaged in fruit browsing habits. Based on dental micro-wear analysis, Merceron (2009) highlights fruit browsing habits for a late Miocene sample of Dorcatherium naui from Atzelsdorf in Austria. The result for P. seegrabensis is the clear exclusion of obligate grazing habits as well as strict browsing habits. Results support similarities with fruit browsers and generalists. Furthermore, E. clavatus displays a dental wear pattern similar to that of extant leaf browsers. However, the small sample size prevents us from reaching a definitive conclusion, since the dental micro-wear pattern could reflect seasonal feeding habits, although the interpretation presented here is consistent with earlier works conducted on Eotragus from Sansan (early middle Miocene of France). The authors conclude that both morphological and dental micro-wear analyses support browsing habits (Solounias and Moelleken, 1992). Such ecological plasticity for a mixed feeding species is not unexpected since they are tolerant in both feeding and habitat preferences. Among all of the middle Miocene ruminants studied here, the species of Palaeomerycidae are the ones sharing the most affinities with leaf browsing species.

In Göriach, the presence of browsing species such as Deinotherium (Calandra et al., 2008, 2010) and the perissodactyls Tapirus and Anchitherium (MacFadden, 2001; Kaiser, 2009; Tütken and Vennemann, 2009) testifies to wooded conditions in good agreement with the cenogram. Also, the rhinoceros Hoploaceratherium is thought to be adapted to humid conditions and forest environments (Becker, 2003). Several small mammals also point to humid conditions, such as Cricetodon and Lanthanotherium (Rummel, 1999; Engesser, 2009), and both beavers Chalicomys and Trogontherium indicate a stretch of freshwater nearby (Hugueney, 1999). 
However, others species thought also to be synonymous with forested areas such as Dorcatherium (Rössner, 2007), Euprox, Dicrocerus or even Eotragus (Solounias and Moelleken, 1994), are here depicted as ruminants involved in both grazing and browsing. It is important to note, however, that even in present-day central African evergreen rainforests, ungulates are able to browse and graze on growing herbaceous dicots and monocots, especially in clearings, which play a major ecological role. Moreover, floristic data do not support evergreen forests in Central Europe during the middle Miocene but a warm and humid tropical forest, which today offers greater diversity of habitats than evergreen forests. Such conditions could have prevailed along the Central Paratethys lakeshores but also uplands along the rivers streaming down.

Some genera in common with Göriach point to forest habitats in the vicinity of Devínska Novà Ves Zapfe's fissure site, such as Hoploaceratherium, or to humid conditions like Cricetodon. Two other cricetids, Eumyarion and Democricetodon, are also interpreted as markers of humid conditions (van de Weerd and Daams, 1978). Plesiodymilus and Blackia (flying squirrels) are obviously forest dwellers (De Bruijn, 1999; Engesser, 2009), while Keramidomys would indicate humid conditions (Hugueney, 1984). As mentioned above, although Dicrocerus and Dorcatherium occurring in Devínska Novà Ves Zapfe's fissure site, may have preferred wooded landscapes, they had wider arrays of feeding habits than previously thought. More open landscapes are represented by several species including the sciurid Spermophilinus, a ground squirrel, and the fossorial talpid Talpa, which were both probably adapted to moist meadows (Engesser, 2009).

\section{Conclusions}

Simpson (1949) and MacArthur and Wilson (1967) proposed the hypothesis that heterogeneity of habitats (i.e., a variety of vegetation formations coexisting at local or regional scale) could positively influence species diversity and favour sympatric speciation by providing more ecological niches and diverse ways of exploiting environmental resources. This theory has since been extensively studied in ecology and evolutionary biology (Dornelas et al., 2009; Griffin et al., 2009). Several studies based on extant mammals have indeed confirmed a positive relationship between the heterogeneity of habitats and mammalian taxonomic richness at a regional scale (Kerley, 1992; Kerr and Packer, 1997; Williams and Marsh, 1998; Williams et al., 2002). If these observations have been made for different groups of mammals, it has especially been observed for primates (Schwarzkopf and Rylands, 1999). The main outcome of our results supports the presence of mosaic landscapes across the different localities analysed at a regional scale with an abundant herbaceous layer (including graminoids) under humid conditions along the western Central Paratethys shores and its hinterland during the middle Miocene. The existence of heterogeneous habitats in Central Europe during the middle Miocene, as illustrated by our results, provided the necessary conditions for a diversification of ecological niches supporting the relatively high taxonomic richness of ruminants and primates observed, and might have even contributed to the diversification of these groups in Europe.

\section{Acknowledgements}

GM and UBG appreciate the support of the FWF (Austria) and especially the Lise Meitner program MB-1050-B17 for supporting this study in collaboration with the Natural History Museum of Vienna, Austria. OM's research is supported by the Chinese National Natural Science Foundation (41050110135) and a Research Fellowship for International Young Researchers from the Chinese Academy of Sciences (2009Y2BZ3).

GM and UBG are grateful to Dr. M. Gross (Landesmuseum Joanneum Museum, Austria) and Dr. D. Nagel (University of Vienna, Austria) for giving access to the collections of fossil mammals. LC thanks J. van der Made for sharing his opinions and references on Eotragus. Finally, two anonymous reviewers have provided instructive and detailed comments that have contributed to the improvement of this study.

\section{Appendix A}

Summary statistics (mean [m] and standard error of the mean [sem]) of dental micro-wear variables on extant species clustered by diet category.

\begin{tabular}{|c|c|c|c|c|c|c|c|c|c|c|c|c|c|c|c|c|}
\hline & & \multirow[b]{2}{*}{$\mathrm{N}$} & \multicolumn{2}{|c|}{ Ns } & \multicolumn{2}{|c|}{$\mathrm{Np}$} & \multicolumn{2}{|c|}{$\mathrm{Pp}(\%)$} & \multicolumn{2}{|c|}{ Ls $(\mu \mathrm{m})$} & \multicolumn{2}{|c|}{ Nws } & \multicolumn{2}{|c|}{ Nlp } & \multicolumn{2}{|c|}{ Tot } \\
\hline & & & $\mathrm{m}$ & sem & $\mathrm{m}$ & sem & $\mathrm{m}$ & sem & $\mathrm{m}$ & sem & $\mathrm{m}$ & sem & $\mathrm{m}$ & sem & $\mathrm{m}$ & sem \\
\hline \multirow[t]{2}{*}{ Leaf browsers } & Giraffa camelopardalis & 16 & 15.1 & 1.3 & 29.3 & 3.7 & 64.0 & 3.4 & 158 & 11.2 & 0.8 & 0.3 & 4.0 & 0.7 & 44.4 & 3.8 \\
\hline & Litocranius walleri & 16 & 15.1 & 0.6 & 34.5 & 4.9 & 66.6 & 2.4 & 142 & 11.8 & 0.9 & 0.2 & 6.8 & 1.4 & 49.6 & 5.0 \\
\hline \multirow[t]{6}{*}{ Leaf/fruit browsers } & Capreolus capreolus & 128 & 21.8 & 0.6 & 32.6 & 1.1 & 58.8 & 1.0 & 127 & 3.0 & 1.0 & 0.1 & 4.8 & 0.2 & 54.4 & 1.3 \\
\hline & Odocoileus virginianus & 11 & 19.9 & 1.8 & 31.1 & 3.3 & 60.1 & 4.0 & 126 & 10.6 & 1.2 & 0.3 & 5.8 & 1.5 & 51.0 & 3.4 \\
\hline & Sylvicapra grimmia & 24 & 20.9 & 1.2 & 39.1 & 3.1 & 63.5 & 2.4 & 156 & 7.4 & 1.1 & 0.2 & 6.0 & 0.8 & 60.1 & 3.0 \\
\hline & Tragelaphus scriptus & 18 & 18.2 & 1.6 & 24.3 & 2.7 & 56.2 & 2.6 & 127 & 6.6 & 1.7 & 0.5 & 8.3 & 1.0 & 42.6 & 3.7 \\
\hline & Tragelaphus strepsiceros & 8 & 14.9 & 1.5 & 31.9 & 4.5 & 66.6 & 3.9 & 138 & 4.0 & 0.6 & 0.3 & 4.5 & 0.8 & 46.8 & 4.8 \\
\hline & Mazama americana & 6 & 23.3 & 3.4 & 28.8 & 6.6 & 52.9 & 8.5 & 143 & 11.6 & 1.3 & 0.6 & 4.7 & 1.3 & 52.2 & 4.8 \\
\hline \multirow[t]{2}{*}{ Fruit browsers } & Cephalophus sylvicultor & 8 & 19.9 & 1.6 & 34.6 & 4.7 & 62.3 & 3.2 & 184 & 18.5 & 1.4 & 0.6 & 5.6 & 1.5 & 54.5 & 5.4 \\
\hline & Cephalophus dorsalis & 19 & 27.2 & 2.1 & 45.6 & 4.0 & 61.6 & 3.3 & 135 & 5.2 & 3.0 & 0.5 & 7.9 & 1.0 & 72.7 & 4.0 \\
\hline \multirow[t]{6}{*}{ Generalists } & Cervus elaphus & 47 & 26.4 & 0.9 & 36.9 & 2.2 & 56.7 & 1.7 & 190 & 5.3 & 1.4 & 0.2 & 5.5 & 0.5 & 63.3 & 2.3 \\
\hline & Rangifer tarandus & 17 & 24.4 & 2.8 & 55.8 & 4.2 & 69.4 & 3.2 & 111 & 8.2 & 1.2 & 0.4 & 6.4 & 0.9 & 80.2 & 4.5 \\
\hline & Ovis ammon & 9 & 27.0 & 3.7 & 50.9 & 11.7 & 58.3 & 9.1 & 139 & 11.2 & 0.7 & 0.2 & 7.1 & 2.8 & 77.9 & 8.4 \\
\hline & Ovibos moschatus & 8 & 23.8 & 3.8 & 47.3 & 7.4 & 65.2 & 6.2 & 144 & 10.0 & 1.4 & 0.5 & 7.1 & 2.3 & 71.0 & 6.5 \\
\hline & Rupicapra rupicapra & 21 & 28.9 & 1.9 & 30.2 & 3.9 & 47.9 & 4.1 & 150 & 6.1 & 1.8 & 0.3 & 4.6 & 0.6 & 59.1 & 3.6 \\
\hline & Muntiacus muntjak & 8 & 28.0 & 2.7 & 51.1 & 3.9 & 64.4 & 3.5 & 140 & 11.0 & 0.8 & 0.3 & 4.0 & 0.8 & 79.1 & 3.7 \\
\hline \multirow[t]{7}{*}{ Grazers } & Damaliscus lunatus & 14 & 22.6 & 1.4 & 12.7 & 1.9 & 33.7 & 2.6 & 137 & 8.6 & 1.5 & 0.4 & 3.9 & 0.6 & 35.4 & 3.1 \\
\hline & Hippotragus niger & 13 & 27.7 & 1.1 & 14.2 & 2.0 & 32.3 & 2.9 & 175 & 8.3 & 2.8 & 0.4 & 4.0 & 1.0 & 41.9 & 2.7 \\
\hline & Kobus kob & 26 & 26.3 & 0.9 & 16.9 & 1.5 & 37.4 & 2.3 & 178 & 8.1 & 2.7 & 0.3 & 3.9 & 0.5 & 43.2 & 1.9 \\
\hline & Ourebia ourebi & 18 & 22.8 & 1.1 & 20.9 & 3.1 & 44.2 & 4.2 & 173 & 5.0 & 1.8 & 0.4 & 2.8 & 0.5 & 43.6 & 3.0 \\
\hline & Syncerus caffer & 24 & 24.6 & 1.4 & 13.2 & 1.3 & 33.8 & 1.9 & 181 & 9.5 & 2.6 & 0.3 & 3.7 & 0.3 & 37.8 & 2.4 \\
\hline & Alcelaphus buselaphus & 36 & 28.0 & 0.9 & 17.8 & 1.4 & 37.4 & 1.5 & 154 & 6.6 & 1.9 & 0.3 & 3.1 & 0.4 & 45.8 & 2.0 \\
\hline & Connochaetes gnu & 10 & 24.9 & 1.4 & 14.1 & 1.8 & 35.0 & 3.0 & 195 & 9.0 & 3.3 & 0.4 & 2.5 & 0.4 & 39.0 & 2.6 \\
\hline
\end{tabular}

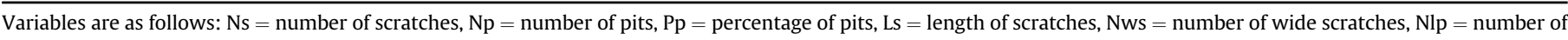
large pits, Tot $=$ total number of micro-wear scars. 


\section{Appendix B}

Summary statistics (mean $[\mathrm{m}]$ and standard error of the mean [sem]) of dental micro-wear variables on extinct taxa clustered by sites.

\begin{tabular}{|c|c|c|c|c|c|c|c|c|c|c|c|c|c|c|c|c|}
\hline \multirow[t]{2}{*}{ Species } & \multirow[t]{2}{*}{ Localities } & \multirow[b]{2}{*}{$\mathrm{N}$} & \multicolumn{2}{|c|}{ Ns } & \multicolumn{2}{|c|}{$\mathrm{Np}$} & \multicolumn{2}{|c|}{$\mathrm{Pp}(\%)$} & \multicolumn{2}{|c|}{ Ls $(\mu \mathrm{m})$} & \multicolumn{2}{|c|}{ Nws } & \multicolumn{2}{|c|}{ Nlp } & \multicolumn{2}{|c|}{ Tot } \\
\hline & & & $\mathrm{m}$ & sem & $\mathrm{m}$ & sem & $\mathrm{m}$ & sem & $\mathrm{m}$ & sem & $\mathrm{m}$ & sem & $\mathrm{m}$ & sem & $\mathrm{m}$ & sem \\
\hline \multirow[t]{3}{*}{ Dicroceros elegans } & Göriach & 16 & 31.3 & 1.9 & 24.4 & 3.2 & 48.0 & 4.4 & 202.2 & 12.5 & 4.3 & 0.8 & 3.7 & 1.0 & 62.9 & 3.4 \\
\hline & Leoben & 1 & 29.0 & - & 33.0 & - & 53.2 & - & 228.5 & - & 4.0 & - & 5.0 & - & 62.0 & - \\
\hline & DNV Zapfe fissure & 2 & 33.0 & 0.0 & 9.0 & 4.5 & 30.8 & 5.8 & 194.1 & 9.8 & 4.0 & 3.0 & 1.5 & 1.5 & 48.0 & 4.0 \\
\hline \multirow[t]{3}{*}{ Dorcatherium crassum } & Göriach & 9 & 33.0 & 1.3 & 24.8 & 4.4 & 45.8 & 4.8 & 165.0 & 10.2 & 2.7 & 0.6 & 6.1 & 0.8 & 64.8 & 6.6 \\
\hline & Leoben & 1 & 25.0 & - & 34.0 & - & 57.6 & - & 194.0 & - & 4.0 & - & 0.0 & - & 59.0 & \\
\hline & Eibiswald & 2 & 29.0 & 0.0 & 43.0 & 11.0 & 58.8 & 6.3 & 175.1 & 0.2 & 4.0 & 1.0 & 10.0 & 1.0 & 72.0 & 11.0 \\
\hline \multirow[t]{3}{*}{ Dorcatherium vindebonense } & Leoben & 7 & 27.1 & 3.5 & 24.3 & 6.8 & 43.2 & 9.4 & 206.2 & 23.3 & 3.4 & 0.6 & 3.6 & 1.2 & 51.4 & 5.2 \\
\hline & DNV Zapfe fissure & 5 & 29.8 & 5.5 & 29.2 & 6.2 & 56.8 & 7.1 & 150.5 & 24.1 & 3.4 & 1.1 & 8.0 & 3.4 & 73.6 & 12.4 \\
\hline & Eibiswald & 1 & 31.0 & - & 15.0 & - & 32.6 & - & 187.9 & - & 6.0 & - & 4.0 & - & 46.0 & - \\
\hline Eotragus clavatus & Göriach & 2 & 18.5 & 0.5 & 37.5 & 4.5 & 72.3 & 3.0 & 184.7 & 50.2 & 1.0 & 1.0 & 6.0 & 2.0 & 67.5 & 5.5 \\
\hline Pseudoeotragus seegrabensis & Leoben & 26 & 28.2 & 1.4 & 32.2 & 3.3 & 50.7 & 3.1 & 164.5 & 6.8 & 3.6 & 0.5 & 5.0 & 0.6 & 60.4 & 2.8 \\
\hline Euprox minimus & Göriach & 8 & 30.6 & 3.0 & 18.6 & 4.8 & 43.2 & 6.7 & 180.2 & 15.7 & 4.0 & 0.7 & 3.8 & 0.7 & 56.0 & 3.5 \\
\hline \multirow[t]{2}{*}{ Heteroprox larteti } & Leoben & 4 & 32.8 & 6.1 & 22.3 & 5.3 & 40.9 & 9.9 & 182.4 & 8.8 & 4.8 & 0.6 & 4.5 & 1.7 & 55.0 & 2.0 \\
\hline & DNV Zapfe fissure & 1 & 33.0 & - & 25.0 & - & 46.8 & - & 159.0 & - & 3.0 & - & 7.0 & - & 62.0 & - \\
\hline Ampelomeryx magnus & DNV Zapfe fissure & 2 & 18.5 & 1.5 & 19.8 & 16.8 & 52.0 & 21.0 & 198.5 & 4.0 & 4.0 & 2.0 & 1.0 & 1.0 & 46.0 & 17.0 \\
\hline \multirow[t]{2}{*}{ Palaeomeryx kaupi } & Leoben & 2 & 21.5 & 6.5 & 29.5 & 23.5 & 47.8 & 30.1 & 157.9 & 39.4 & 3.0 & 2.0 & 7.0 & 4.0 & 51.0 & 17.0 \\
\hline & Eibiswald & 3 & 25.3 & 1.8 & 26.3 & 3.8 & 50.6 & 2.3 & 206.1 & 18.2 & 2.0 & 1.0 & 3.7 & 2.0 & 51.7 & 5.4 \\
\hline Palaeomeryx eminens & Göriach & 1 & 26.0 & - & 11.5 & - & 40.9 & - & 154.8 & - & 5.0 & - & 3.0 & - & 44.0 & - \\
\hline
\end{tabular}

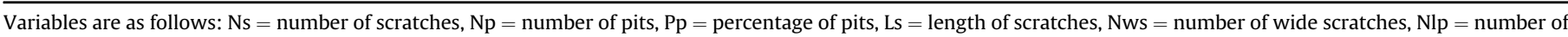
large pits, Tot $=$ total number of micro-wear scars.

\section{Appendix C}

The ANOVA on extant and extinct ruminants detects significant between-species differences in all variables.

\begin{tabular}{|c|c|c|c|c|c|c|}
\hline & & $d f$ & SS & $M S$ & $F$ & $p$ \\
\hline \multirow[t]{3}{*}{$\mathrm{Pp}$} & Species & 14 & $6,477,445$ & 462,675 & 23.7812 & $<0.001$ \\
\hline & Residuals & 583 & $11,342,526$ & 19,455 & & \\
\hline & Total & 597 & $17,819,972$ & & & \\
\hline \multirow[t]{3}{*}{ Ns } & Species & 14 & $4,436,128$ & 316,866 & 13.8306 & $<0.001$ \\
\hline & Residuals & 583 & $13,356,854$ & 22,911 & & \\
\hline & Total & 597 & $17,792,982$ & & & \\
\hline \multirow[t]{3}{*}{$\mathrm{Np}$} & Species & 14 & $5,892,836$ & 420,917 & 20.5874 & $<0.001$ \\
\hline & Residuals & 583 & $11,919,649$ & 20,445 & & \\
\hline & Total & 597 & $17,812,484$ & & & \\
\hline \multirow[t]{3}{*}{ Ls } & Species & 14 & $3,459,078$ & 247,077 & 10.0300 & $<0.001$ \\
\hline & Residuals & 583 & $14,361,472$ & 24,634 & & \\
\hline & Total & 597 & $17,820,550$ & & & \\
\hline \multirow[t]{3}{*}{ Nws } & Species & 14 & $3,888,707$ & 277,765 & 12.2762 & $<0.001$ \\
\hline & Residuals & 583 & $13,191,150$ & 22,626 & & \\
\hline & Total & 597 & $17,079,857$ & & & \\
\hline \multirow[t]{3}{*}{ Nlp } & Species & 14 & $1,852,557$ & 132,325 & 4.8927 & $<0.01$ \\
\hline & Residuals & 583 & $15,767,473$ & 27,045 & & \\
\hline & Total & 597 & $17,620,030$ & & & \\
\hline \multirow[t]{3}{*}{ Tot } & Species & 14 & $5,232,524$ & 373,752 & 17.3187 & $<0.001$ \\
\hline & Residuals & 583 & $12,581,616$ & 21,581 & & \\
\hline & Total & 597 & $17,814,139$ & & & \\
\hline
\end{tabular}

$d f$ : degree of freedom; SS: Sum of Squares; MS: Mean of Squares; F: F-statistic value.

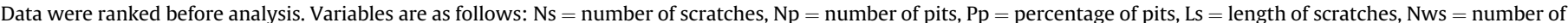
wide scratches, $\mathrm{Nlp}=$ number of large pits, Tot $=$ total number of micro-wear scars. 
Appendix D

Faunal lists and body weight estimations for the mammal assemblages (excluding the guild of carnivores) from Göriach and Devínska Novà Ves Zapfe's fissures.

\begin{tabular}{|c|c|c|}
\hline Göriach & $\begin{array}{l}\text { Body } \\
\text { mass (g) }\end{array}$ & References \\
\hline Deinotherium giganteum & $19,375,245$ & Tobien, 1988 \\
\hline Zygolophodon turicensis & $4,381,249$ & Costeur et al., in press \\
\hline $\begin{array}{l}\text { Hoploaceratherium } \\
\text { tetradactylum }\end{array}$ & $1,000,000$ & Costeur et al., in press \\
\hline Dicerorhinus steinheimense & $619,731.2$ & Guérin, 1980 \\
\hline Palaeomeryx eminens & 453,282 & $\begin{array}{l}\text { Costeur, unpublished } \\
\text { data from Steinheim }\end{array}$ \\
\hline Tapirus telleri & $189,624.7$ & $\begin{array}{l}\text { Costeur, 2005a, } \\
\text { b - average Miocene Tapirus }\end{array}$ \\
\hline Anchitherium aurelianense & 179,383 & Abusch-Siewert, 1983 \\
\hline Palaeomeryx bojani & 156,641 & $\begin{array}{l}\text { Costeur, unpublished } \\
\text { data from Artenay }\end{array}$ \\
\hline Conohyus simorrensis & 125,574 & Made, 1989 \\
\hline Dicroceros elegans & 49,016 & Azanza, 2000 \\
\hline Euprox minimus & 41,524 & $\begin{array}{l}\text { Costeur, 2005a, } \\
\text { b - average } \\
\text { Miocene Euprox }\end{array}$ \\
\hline Dorcatherium vindebonense & $39,198.3$ & Mottl, 1970 \\
\hline Dorcatherium crassum & $29,630.8$ & Mottl, 1970 \\
\hline Eotragus clavatus & 26,754 & Mottl, 1970 \\
\hline Albanohyus pygmaeus & $21,000.1$ & Mein, 1958 \\
\hline Orygotherium escheri & $18,970.6$ & Rössner and Mörs, 2001 \\
\hline Micromeryx styriacus & 9956 & $\begin{array}{l}\text { Costeur, 2005a, } \\
\text { b - average } \\
\text { Miocene Micromeryx }\end{array}$ \\
\hline Pliopithecus antiquus & 6289 & Zapfe, 1960 \\
\hline Chalicomys jaegeri & 6198.1 & Agustí, 1978 \\
\hline Lagomeryx parvulus & 5800 & Rössner, 2010a, b \\
\hline Trogontherium minutum & 991.9 & $\begin{array}{l}\text { Costeur, 2005a, } \\
\mathrm{b} \text { - average } \\
\text { Miocene Trogontherium }\end{array}$ \\
\hline Miopetaurista gibberosus & 591.8 & $\begin{array}{l}\text { Costeur, 2005a, } \\
\text { b - average } \\
\text { Miocene Miopetaurista }\end{array}$ \\
\hline Erinaceidae indet. & 500 & $\begin{array}{l}\text { Costeur, 2005a, } \\
\text { b - average early } \\
\text { middle Miocene Erinaceidae }\end{array}$ \\
\hline Lanthanotherium sp. & 200 & $\begin{array}{l}\text { Costeur, 2005a, } \\
\text { b - average } \\
\text { Miocene Lantanotherium }\end{array}$ \\
\hline Muscardinus sansaniensis & 114.1 & Baudelot, 1965 \\
\hline Cricetodon sp. & 90 & $\begin{array}{l}\text { Costeur, 2005a, } \\
\mathrm{b} \text { - average } \\
\text { Miocene Cricetodon }\end{array}$ \\
\hline
\end{tabular}

\begin{tabular}{lrl}
\hline $\begin{array}{l}\text { Devínska Novà } \\
\text { Ves Zapfe's fissures }\end{array}$ & \multicolumn{1}{c}{ Body } & \multicolumn{1}{c}{ References } \\
\hline Prodeinotherium bavaricum $(\mathrm{g})$ & \\
Zygolophodon turicensis & $5,423,904$ & Koufos et al., 2003 \\
Hoploaceratherium tetradactylum & $4,381,249$ & Costeur et al., in press \\
Dicerorhinus steinheimense & $619,00,000$ & Costeur et al., in press \\
Anisodon grande & 509,122 & Cuérin, 1980 \\
Ampelomeryx magnus & $331,999.7$ & Astibia, in press \\
Hyotherium soemmeringi & $100,132.6$ & Mottl, 1970 \\
Heteroprox larteti & $49,159.4$ & Azanza, 2000 \\
Dicroceros elegans & 49,016 & Azanza, 2000 \\
Dorcatherium vindebonense & $44,945.3$ & Mottl, 1970 \\
Aureliachoerus aurelianense & 42,157 & Costeur, unpublished \\
& & data from Artenay \\
Eotragus clavatus & 26,754 & Mottl, 1970 \\
Pliopithecus vindoboniensis & 5929 & Zapfe, 1960 \\
Amphechinus intermedius & 540 & Engesser, 2009 \\
Lantanotherium sansaniense & 225 & Baudelot, 1972 \\
Spermophilinus bredai & 116.3 & Maridet, 2003 \\
Cricetodon sansaniensis & 114.1 & Maridet and Sen, in press \\
Myoglis larteti & 84.4 & Baudelot, 1965 \\
Bransatoglis astaracensis & 73.4 & Engesser, 2009 \\
Lartetomys cf. zapfei & 61.9 & Mörs et al., 2000 \\
Blackia miocenica & 61.14 & Engesser, 1972 \\
& &
\end{tabular}

(continued)

\begin{tabular}{lrl}
\hline $\begin{array}{l}\text { Devínska Novà } \\
\text { Ves Zapfe's fissures }\end{array}$ & $\begin{array}{c}\text { Body } \\
\text { mass (g) }\end{array}$ & \multicolumn{1}{c}{ References } \\
\hline Dinosorex zapfei & 57.8 & Engesser, 1975 \\
Neocometes brunonis & 47.8 & Schaub and Zapfe, 1953 \\
Eumyarion latior & 38.1 & Schaub and Zapfe, 1953 \\
Anomalomys gaudryi & 37.3 & Schaub and Zapfe, 1953 \\
Eumyarion weinfurteri & 32.7 & Schötz, 1993 \\
Miodyromys hamadryas & 32.1 & Engesser, 1972 \\
Plesiodimylus chantrei & 30.6 & Mörs et al., 2000 \\
Megacricetodon gregarius & 29.8 & Schaub, 1925 \\
Democricetodon vindobonensis & 20.5 & Schaub and Zapfe, 1953 \\
Microdyromys miocaenicus & 13.8 & Baudelot, 1972 \\
'Scaptonyx' edwardsi & 13.7 & Ziegler and Falbusch, 1986 \\
Megacricetodon schaubi & 11.1 & Engesser, 2009 \\
'Allosorex' gracilidens & 10 & Estimates in Costeur, 2005a, b \\
Talpa minuta & 10 & Engesser, 2009 \\
?Urotrichus dolichochir & 7.9 & Kowalski, 1989 \\
Lartetium dehmi & 7.2 & Ziegler and Falbusch, 1986 \\
Eomyops sp. & 6.2 & Costeur, 2005a, \\
& & b - average Miocene Eomyops \\
Keramidomys carpathicus & 2.9 & Hugueney, in press \\
Talpidae indet. & - & \\
\hline & &
\end{tabular}

\section{References}

Abramoff, M.D., Magelhaes, P.J., Ram, S.J., 2004. Image processing with image. J. Biophotonics Int. 11, 36-42.

Abusch-Siewert, S., 1983. Gebissmorphologische Untersuchungen an eurasiatischen Anchitherien (Equidae, Mammalia) unter besonderer Berücksichtigung der Fundstelle Sandelzhausen. Cour. Forsch.-Inst. Senckenberg 62, 1-401.

Agustí, J., 1978. El Vallesiense inferior de la Península Ibérica y su fauna de roedores (MAMM.). Acta Geol. Hispánica 13, 137-141.

Astibia, $\mathrm{H}$., in press. Les Palaeomerycidae (Artiodactyla) du gisement Astaracien de Sansan. In: Peigné, S., Sen, S. (Eds.), Les Mammifères du Miocène Moyen de Sansan. Mémoires du Muséum National d'Histoire Naturelle.

Azanza, B., 2000. Los Cervidae (Artiodactyla, Mammalia) del Mioceno de las cuencas del Duero, Tajo, Calatayud-Teruel y Levante. Memorias Del Museo Paleontologico De La Universidad De Zaragosa 8, 1-376.

Baudelot, S., 1965. Complément à l'étude de la faune des rongeurs de Sansan: les Gliridés. Bull. Soc. Géol. Fr. 7, 758-764.

Baudelot, S., 1972. Etude des chiroptères, insectivores et rongeurs du Miocène de Sansan (Gers). Ph.D. Dissertation, University Toulouse.

Becker, D., 2003. Paléoécologie et paléoclimats de la Molasse du Jura (OligoMiocène): apport des Rhinocerotoidea (Mammalia) et des minéraux argileux. Geofocus 9, 1-327.

Begun, D.R., Nargolwalla, M.C., Hutchison, M.P., 2006. Primate diversity in the Pannonian Basin: In situ evolution, disperals, or both? Beitr. Paläontol. 30, 1-12.

Berger, W., 1951. Pflanzenreste aus dem tortonischen Tegelvon Theben-Neudorf bei Pressburg. Sitzber. Osterr. Akad. Wiss. Math.-Nat. Kl. 160, 273-278.

Böhme, M., 2003. The Miocene climatic optimum: evidence from ectothermic vertebrates of central Europe. Palaeogeogr. Palaeoclimatol. Palaeoecol. 195, 389-401.

Böhme, M., 2004. Migration history of air-breathing fishes reveal Neogene atmospheric circulation pattern. Geology 32, 393-396.

Böhme, M., Winkelhofer, M., Ilg, A., 2011. Miocene precipitation in Europe temporal trends and spatial gradients. Palaeogeogr. Palaeoclimatol. Palaeoecol. $304,212-218$

Bruch, A.A., Utescher, T., Mosbrugger, V., Members, N., 2011. Precipitation patterns in the Miocene of central Europe and the development of continentality. Palaeogeogr. Palaeoclimatol. Palaeoecol. 304, 202-211.

Calandra, I., Göhlich, U.B., Merceron, G., 2008. How could sympatric megaherbivores coexist? Example of niche partitioning within a proboscidean community from the Miocene of Europe. Naturwissenschaften 95, 831-838.

Calandra, I., Göhlich, U.B., Merceron, G., 2010. Feeding preferences of Gomphotherium subtapiroideum (Proboscidea, Mammalia) from the Miocene of Sandelhauzen (Northern Alpine Foreland basin, southern Germany) through life and geological time: evidence from dental microwear analysis. Paläeontol. Z. 84, 205-215.

Conover, W.J., Iman, R.L., 1981. Rank transformations as a bridge between parametric and nonparametric statistics. Am. Statist. 35, 124-129.

Costeur, L., 2005a. Cenogram analysis of the Rudabánya mammalian community: palaeoenvironmental interpretations. Palaeontogr. It 90, 303-307.

Costeur, L., 2005b. Les communautés de mammifères d'Europe de l'Oligocène supérieur au Pliocène inférieur: paléobiogéographie et paléobiodiversité des ongulés, paléoenvironnements et paléoécologie évolutive. Ph.D. Dissertation, Université Claude Bernard Lyon I.

Costeur, L., Legendre, S., 2008. Spatial and temporal variation in European Neogene large mammals diversity. Palaeogeogr. Palaeoclimatol. Palaeoecol. 261, 127-144. 
Costeur, L., Montuire, S., Legendre, S., Maridet, O., 2007. The Messinian event: what happened to the peri-Mediterranean mammalian communities and local climate? Geobios 40, 423-431.

Costeur, L., Guerin, C., Maridet, O., in press. Paleoecologie et paleoenvironnement du site Miocene de Sansan. In: Peigne, S., Sen, S. (Eds.), Les Mammiferes du Miocene Moyen de Sansan. Mémoires du Muséum National d'Histoire Naturelle.

Croft, D.A., 2001. Cenozoic environmental change in South America as indicated by mammalian body size distributions (cenograms). Divers. Distrib 7 , 271-287.

Daxner-Höck, G., Miklas-Tempfer, P.M., Göhlich, U.B., Huttunen, K., Kazàr, E., Nagel, D., Roessner, G.E., Schultz, O., Ziegler, R., 2004. Marine and terrestrial vertebrates from the middle Miocene of Grund (lower Austria). Geol. Carp 55, $1-7$.

De Bruijn, H., 1999. Superfamily Sciuroidea. In: Rössner, G.E., Heissig, K. (Eds.), The Miocene Land Mammals of Europe. Verlag Friedrich Pfeil, München, pp. 271-280.

de Bonis, L., Bouvrain, G., Geraads, D., Koufos, G.D., 1992. Diversity and paleoecology of Greek late Miocene mammalian faunas. Palaeogeogr. Palaeoclimatol. Palaeoecol. 91, 99-121.

DeMiguel, D., Fortelius, M., Azanza, B., Morales, J., 2008. Ancestral feeding state of ruminants reconsidered: earliest grazing adaptation claims a mixed condition for Cervidae. BMC Evol. Biol. 8, 1-13.

DeMiguel, D., Azanza, B., Morales, J., 2010. Trophic flexibility within the oldest Cervidae lineage to persist through the Miocene Climatic Optimum. Palaeogeogr. Palaeoclimatol. Palaeoecol. 289, 81-92.

DeMiguel, D., Azanza, B., Morales, J., 2011. Paleoenvironments and paleoclimate of the Middle Miocene of central Spain: a reconstruction from dental wear of ruminants. Palaeogeogr. Palaeoclimatol. Palaeoecol. 302, 452-463.

Deng, T., 2009. Late Cenozoic environmental changes in the Linxia basin (Gansu, China) as indicated by cenograms of fossil mammals. Vert. Palasiat 47, 282-298.

Dornelas, M., Moonen, A.C., Magurran, A.E., Bàrberi, P., 2009. Species abundance distributions reveal environmental heterogeneity in modified landscapes. J. Appl. Ecol. 46, 666-672.

Duranthon, F., Moya-Sola, S., Astibia, H., Köhler, M., 1995. Ampelomeryx ginsburgi nov. gen., nov. sp. (Artiodactyla, Cervoidea) et la famille des Palaeomerycidae. C.R. Acad. Sci. 321, 339-346. Paris.

Engesser, B., 1972. Die obermiozäne Säugetierfauna von Anwil (Baselland). Tätigkeitsberichte Der Naturforschenden Gesellschaft Baselland 28, 37-363.

Engesser, B., 1975. Revision der europäischen Heterosoricinae (Insectivora, Mammalia). Eclogae Geol. Helv. 68, 649-671.

Engesser, B., 2009. The insectivores (Mammalia) from Sansan (Middle Miocene, south-western France). Schweiz. Paläontol. Abh. 128, 1-91.

Eronen, J.T., Rook, L., 2004. The Mio-Pliocene European primate fossil record: dynamics and habitat tracking. J. Hum. Evol. 47, 323-341.

Gomes Rodrigues, H., Merceron, G., Viriot, L., 2009. Dental microwear patterns of extant and extinct Muridae (Rodentia, Mammalia): ecological implications. Naturwissenschaften 96, 537-542.

Griffin, J.N., Jenkins, S.R., Gamfeldt, L., Jones, D., Hawkins, S.J., Thompson, R.C., 2009. Spatial heterogeneity increases the importance of species richness for an ecosystem process. Oikos 118, 1335-1342.

Grine, F.E., 1986. Dental evidence for dietary differences in Australopithecus and Paranthropus: a quantitative analysis of permanent molar microwear. J. Hum. Evol. 15, 783-822.

Gross, M., 2002. Aus der paläontologischen Sammlung des Landesmuseums Joanneum - die fossilen Schildkröten (Testudines). Joannea Geol. Paläont 4, 5-68.

Gross, M., Martin, J., 2008. From the palaeontological collection of the Provincial Museum Joanneum - the fossil crocodilians (Crocodylia). Joannea Geol. Paläont 10, 91-125.

Gross, M., Ingomar, F., Piller, W.E., Soliman, A., Harzhauser, M., Hubmann, B., Moser, B., Scholger, R., Suttner, T.J., Bojar, H.-P., 2007. The Neogene of the Styrian basin - guide to excursions. Joannea Geol. Paläont 9, 117-194.

Guérin, C., 1980. Les rhinoceros (Mammalia, Perissodactyla) du Miocène terminal au Pléistocène supérieur en Europe occidentale. Comparaison avec les espèces actuelles. Documents du Laboratoire de Géologie de L'Université de Lyon 79, $1-401$.

Handler, R., Ebner, F., Neubauer, F., Bojar, A.-V., Hermann, S., 2006. ${ }^{40} \mathrm{Ar} /{ }^{39} \mathrm{Ar}$ dating of Miocene tuffs from the Styrian part of the Pannonian Basin: an attempt to refine the basin stratigraphy. Geol. Carp 57, 483-494.

Heissig, K., 1989. The faunal succession of the Bavarian Molasse reconsidered correlation of the MN5 and MN6 faunas. In: Lindsay, E.H., Fahlbusch, V., Mein, P. (Eds.), European Neogene Mammal Chronology. NATO ASI Series A. Plenum Press, London, pp. 181-192.

Hofmann, A., 1893. Die Fauna von Göriach. Abhandlungen der kaiserlich-königlichen geologischen Reichsanstalt, Wien 15. 1-87.

Hofmann, A., Zdarsky, A., 1905. Beitrag zur Säugetierfauna von Leoben. Jahrbuch Der Kais. Kön. Reichsanstalt 54, 577-594.

Hugueney, M., 1984. Evolution du paléoenvironnement dans le tertiare de Limagne (Massif Central, France) à partir des faunes de mammifères. Geobios 8, 385-391.

Hugueney, M., 1999. Family Castoridae. In: Rössner, G.E., Heissig, K. (Eds.), The Miocene Land Mammals of Europe. Verlag Friedrich Pfeil, Munich, pp. 281-300.

Hugueney, M., in press. Les Eomyidae (Rodentia) de Sansan. In: Peignè, S., Sen, S. (Eds.), Les Mammifères du Miocéne Moyen de Sansan. Mémoires du Muséum National d'Histoire Naturelle.
Ivanov, D., Ashraf, A.R., Mosbrugger, V., Palamarev, E., 2002. Palynological evidence for Miocene climate change in the Forecarpathian basin (Central Paratethys, NW Bulgaria). Palaeogeogr. Palaeoclimatol. Palaeoecol. 178, 19-37.

Ivanov, D., Ashraf, A.R., Utescher, T., Mosbrugger, V., Slavomirova, E., 2007. Late Miocene vegetation and climate of the Balkan region: palynology of the Beli Breg coal basin sediments. Geol. Carp 58, 367-381.

Ivanov, D., Utescher, T., Mosbrugger, V., Syabryaj, S., Djordjević-Milutinović, D. Molchanoff, S., 2011. Miocene vegetation and climate dynamics in eastern and central Paratethys (Southeastern Europe). Palaeogeogr. Palaeoclimatol. Palaeoecol. 304, 262-275.

Jacobs, L.L., Lindsay, E.H., 1984. Holarctic radiation of Neogene Muroid rodents and the origin of south American cricetids. J. Vert. Paleontol 4, 265-272.

Janis, C.M., 1990. The correlation between diet and dental wear in herbivorous mammals, and its relationship to the determination of diets of extinct species. In: Boucot, A.J. (Ed.), Evolutionary Paleobiology of Behavior and Coevolution. Elsevier, Amsterdam, pp. 241-259.

Kaiser, T.M., 2009. Anchitherium aurelianense (Equidae, Mammalia) - a brachydont 'dirty browser' in the community of herbivorous large mammals from Sandelzhausen (Miocene, Germany). Paläeontol. Z. 83, 131-140.

Kaiser, T.M., Rössner, G.E., 2007. Dietary resource partitioning in ruminan communities of Miocene wetland and karst palaeoenvironments in southern Germany. Palaeogeogr. Palaeoclimatol. Palaeoecol. 252, 424-439.

Kälin, D., 1993. Stratigraphie und Säugetierfaunen der oberen Susswassermolasse der Nordwestschweiz. Eidgenossischen Technischen Hochschule Zurich, Zurich, pp. $1-238$.

Kerley, G.I.H., 1992. Small mammal seed consumption in the Karoo, South Africa: further evidence for divergence in desert biotic processes. Oecologia 89, $471-475$

Kern, A., Harzhauser, M., Mandic, O., Roetzel, R., Ćorić, S., Bruch, A.A., Zuschin, M. 2011. Millennial-scale vegetetation dynamics in an estuary at the onset of Miocene Climatic Optimum. Palaeogeogr. Palaeoclimatol. Palaeoecol. 304 247-261

Kerr, J.T., Packer, L., 1997. Habitat heterogeneity as a determinant of mammal species richness in high-energy regions. Nature 385, 252-254.

Koufos, G.D., Zouros, N., Mourouzidou, O., 2003. Prodeinotherium bavaricum (Proboscidea, Mammalia) from Lesvos Island, Greece; the appearance of deinotheres in the eastern Mediterranean. Geobios 36, 305-315.

Kowalski, K., 1989. History and evolution of the terrestrial fauna of Poland. Folia Quatern 59-60, 1-278.

Legendre, S., 1986. Analysis of mammalian communities from the late Eocene and Oligocene of southern France. Palaeovertebrata 16, 191-212.

Legendre, S., 1989. Les communautés de mammifères du Paléogène (Eocène supérieur et Oligocène) d'Europe occidentale: structures, milieux et évolution. Münchner Geowiss. Abh. A 16, 1-110.

Legendre, S., Crochet, J.-Y., Godinot, M., Hartenberger, J.L., Marandat, B., Remy, J.A., Sigé, B., Sudre, J., Vianey-Liaud, M., 1991. Evolution de la diversité des faunes de mammifères d'Europe occidentale au Paléogène (MP11 à MP30). Bull. Soc. Géol. Fr. 162, 867-874

Legendre, S., Montuire, S., Maridet, O., Escarguel, G., 2005. Rodents and climate: a model for estimating past temperatures using sigmodontines as analogue for Old World cricetines (Mammalia, Rodentia, Muridae s.l). Earth Planet. Sci. Lett. 235, 408-420.

MacArthur, R.H., Wilson, E.O., 1967. The Theory of Island Biogeography. Princeton University Press, Princeton.

MacFadden, B.J., 2001. Three-toed browsing horse Anchitherium clarencei from the early Miocene (Hemingfordian) Thomas Farm, Florida. Bull. Fla. Mus. Nat. Hist. 43, 79-109.

Maridet, O., 2003. Révision du genre Democricetodon (Mammalia, Rodentia, Cricetinae) et dynamique des faunes de rongeurs du Néogène d'Europe occidentale: évolution, paléobiodiversité et paléobiogéographie. Ph.D. Dissertation, Université Claude Bernard Lyon I.

Maridet, O., Sen, S., in press. Les Cricetidae (Rodentia) de Sansan. In: Peigné, S., Sen, S. (Eds.), Les Mammifères du Miocène Moyen de Sansan. Mémoires du Muséum National d'Histoire Naturelle.

Mein, P., 1958. Les mammifères de la faune sidérolithique de Vieux-Collonges. Nouvelles Archives du Musée d'Histoire Naturelle de Lyon 5, 1-122.

Mein, P., Ginsburg, L., 2002. Sur l'âge relatif des différents dépôts karstiques Miocènes de La Grive-Saint-Alban (Isère), vol. 2. Cahiers Scientifiques - Mus. Hist. Nat. Lyon. 7-47.

Merceron, G., 2009. The Atzelsdorf section: a snapshot of the early Vallesian fauna of the palaeo-Danube delta (Austria; Late Miocene; early Pannonian): dental wear patterns of herbivorous ungulates as ecological indicators. Ann. Naturhist. Mus. Wien 111A, 647-660.

Merceron, G., Blondel, C., Brunet, M., Sen, S., Solounias, N., Viriot, L., Heintz, E., 2004a. The late Miocene paleoenvironment of Afghanistan as inferred from dental microwear in artiodactyls. Palaeogeogr. Palaeoclimatol. Palaeoecol. 207, $143-163$.

Merceron, G., Viriot, L., Blondel, C., 2004b. Tooth microwear pattern in roe deer (Capreolus capreolus, L.) from Chizé (Western France) and relation to food composition. Small Ruminant Res. 53, 125-138.

Merceron, G., Blondel, C., Bonis de, L., Koufos, G.D., Viriot, L., 2005. A new dental microwear analysis: application to extant Primates and Ouranopithecus macedoniensis (Late Miocene of Greece). Palaios 20, 551-561.

Merceron, G., Blondel, C., Viriot, L., Koufos, G.D., Bonis de, L., 2007a. Denta microwear analysis on bovids from the Vallesian (Late Miocene) of the Axios 
Valley in Greece: reconstruction of the habitat of Ouranopithecus macedoniensis (Primates, Hominoidea). Geodiversitas 29, 421-433.

Merceron, G., Schulz, E., Kordos, L., Kaiser, T.M., 2007b. Paleoenvironment of Dryopithecus brancoi at Rudabánya, Hungary: evidence from dental meso- and micro-wear analyses of large vegetarian mammals. J. Hum. Evol. 53, 331-349.

Merceron, G., Escarguel, G., Angibault, J.-M., Verheyden-Tixier, H., 2010. Can dental microwear textures record dietary inter-individual dietary variations? Plos One 5, e9542.

Montuire, S., Michaux, J., Legendre, S., Aguilar, J.-P., 1997. Rodents and climate. 1. A model for estimating past temperatures using arvicolids (Mammalia: Rodentia). Palaeogeogr. Palaeoclimatol. Palaeoecol. 128, 187-206.

Montuire, S., Maridet, O., Legendre, S., 2006. Late Miocene-Early Pliocene temperature estimates in Europe using rodents. Palaeogeogr. Palaeoclimatol. Palaeoecol. 238, 247-262.

Mörs, T., von der Hocht, F., Wutzler, B., 2000. Die erste Wirbeltierfauna aus der miozänen Braunkohle der Niederrheinischen Bucht (Ville-Schichten, Tagebau Hambach). Paläeontol. Z 74, 145-170.

Mottl, M., 1970. Die jungtertiären Säugetierfaunen der Steiermark, Südost-Österreichs. Mitteilungen des Museums für Bergbau. Geologie Und Technik Am Landesmuseum Joanneum 31, 3-85.

Musser, G.G., Carleton, M.D., 1993. Family Muridae. In: Wilson, D.E., Reeder, D.M. (Eds.), Mammal Species of the World, second ed.A Taxonomic and Geographic Reference Smithsonian Institution Press and the American Society of Mammalogists, Washington, pp. 501-755.

Made, J., van der, 1989. A Conohyus - lineage (Suidae, Artiodactyla) from the Miocene of Europe. Rev. Esp. Paleontol. 4, 19-28.

Made, J., van der, 1997. Aureliachoerus from Oberdorf and other Aragonian pigs from Styria. Ann. Naturhist. Mus. Wien 99A, 225-277.

Made, J., van der, Knežević, S., Stefanović, I., 2007. A mid-Miocene age for the Slanci Formation near Belgrade (Serbia), based on a record of the primitive antelope Eotragus cf. clavatus from Višnjica. Geološki Anali Balkanskog Poluostrva 68, 53-59.

Made, J. van der, in press. Eotragus clavatus (Boselaphini, Bovidae) du Miocène moyen de Sansan. Mémoires du Muséum National d'Histoire Naturelle.

Nargolwalla, M.C., Huchison, M.P., Begun, D.R., 2006. Middle and late Miocene terrestrial vertebrate localities and paleoenvironments in the Pannonian Basin. Beitr. Paläont. 30, 319-332.

Ramdarshan, A., Merceron, G., Tafforeau, P., Marivaux, L., 2010. Dietary reconstruction of the Amphipithecidae (Primates, Anthropoidea) from the Paleogene of south Asia and paleoecological implications. J. Hum. Evol. 59, 96-108.

Rodriguez, J., 1999. Use of cenograms in mammalian palaeoecology: a critical review. Lethaia 32, 331-347.

Rössner, G.E., 2005. Ruminantia from the Grund formation: correlation of continental and marine deposits and climatic development during early middle Miocene of the central Paratethys (Austria). Geol. Carp 56, 337-345.

Rössner, G.E., 2006. A community of middle Miocene Ruminantia (Mammalia, Artiodactyla) from the German Molasse basin. Palaeontogr. Abt. 1 (277), 103-112.

Rössner, G.E., 2007. Family Tragulidae. In: Prothero, D.R., Foss, S.E. (Eds.), The Evolution of Artiodactyls. The Johns Hopkins University Press, Baltimore, pp. 213-220.

Rössner, G.E., 2010a. Systematics and palaeoecology of Ruminantia (Artiodactyla Mammalia) from the Miocene of Sandelzhausen (southern Germany, northern Alpine Foreland basin). Paläeontol. Z. 84, 123-162.

Rössner, G.E., 2010b. Systematics and palaeoecology of Ruminantia (Artiodactyla, Mammalia) from the Miocene of Sandelzhausen (southern Germany, northern Alpine Foreland basin). In: Rössner, G.E., Göhlich, U.B. (Eds.), Fossil Lagerstätte Sandelzhausen (Miocene Southern Germany) - Contributions to the Fauna II. Paläeontol. Z, 84, pp. 123-162.

Rössner, G.E., Mörs, T., 2001. A new record of the enigmatic Eurasian Miocene ruminant Artiodactyl Orygotherium. J. Paleontol 21, 591-595.

Rummel, M., 1999. Tribe Cricetodontini. In: Rössner, G., Heissig, K. (Eds.), The Miocene Land Mammals of Europe, pp. 359-364. Verlag Friedrich Pfeil, München.

Sabol, M., Holec, P., 2002. Temporal and spatial distribution of Miocene mammals in the western Caparthians (Slovakia). Geol. Carp 53, 269-279.

Sachsenhofer, R.F., Bechtel, A., Reischenbacher, D., Weiss, A., 2003. Evolution of lacustrine systems along the Miocene Mur-Mürz fault system (Eastern Alps, Austria) and implications on source rocks in pullapart basins. Mar. Petrol. Geol. 20, 83-110.
Schaub, S., 1925. Die hamsterartigen Nagetiere des Tertiärs. Abhandlungen Der Schweizerischen Palaeontologischen Gesellschaft 45, 1-100.

Schaub, S., Zapfe, H., 1953. Die Fauna der miozänen Spaltenfüllung von Neudorf an der March (CSR). Sitzungsberichten Der Österreichen Akademie Der Wissenschaften $162,181-215$.

Schötz, M., 1993. Zwei Hamsterfaunen (Rodentia, Mammalia) aus der niederbayerischen Molasse. Mitteilungen Der Bayerischen Staatssammlung Für Paläontologie und Historische Geologie 33, 155-194.

Schwarzkopf, L., Rylands, A.B., 1999. Primate species richness in relation to habitat structure in Amazonian rainforest fragments. Biol. Cons 48, 1-12.

Silva, M., Downing, J.A., 1995. Handbook of Mammalian Body Masses. CRC Press, Boca Raton.

Simpson, E.H., 1949. Measurement of diversity. Nature 163, 688.

Slaughter, B.H., Ubelaker, J.E., 1984. Relationship of south American cricetines to rodents of north America and the Old world. J. Vert. Paleontol 4, 255-264.

Solounias, N., Moelleken, S.M.C., 1992. Cranial restoration of Eotragus sansaniensis (Mammalia: Ruminantia), one the oldest known bovids. J. Vert. Paleontol 12 250-255.

Solounias, N., Moelleken, S.M.C., 1994. Differences in diet between two archaic ruminant species from Sansan, France. Geobios 7, 203-220.

Solounias, N., Semprebon, G., 2002. Advances in the reconstruction of ungulates ecomorphology with application to early fossil equids. Am. Mus. Novit 3366, $1-49$.

Solounias, N., Teaford, M.F., Walker, A., 1988. Interpreting the diet of extinct ruminants: the case of a non-browsing giraffid. Paleobiology 14, 287-300.

Stehlin, H.G., Schaub, S., 1951. Die Trigonodontie der Simplicidentater Nager. Schweiz. Paläontol. Abh. 67, 1-385.

Teaford, M.F., Oyen, O.J., 1989. In vivo and in vitro turnover in dental microwear. Am. J. Phys. Anthropol. 80, 447-460.

Teaford, M.F., Robinson, J.G., 1989. Seasonal or ecological differences in diet and molar microwear in Cebus nigrivittatus. Am. J. Phys. Anthropol. 80, 391-401.

Teaford, M.F., Walker, A., 1984. Quantitative differences in dental microwear between primate species with different diets and a comment on the presumed diet of Sivapithecus. Am. J. Phys. Anthropol. 64, 191-200.

Tobien, H., 1988. Contributions à l'étude du gisement Miocène supérieur de Montredon (Hérault). Les grands mammifères. 7. Les proboscidiens Deinotheriidae. Palæovertebrata, Mémoire Extraordinaire, 135-175.

Travouillon, K.J., Legendre, S., 2009. Using cenograms to investigate gaps in mammalian body mass distributions in Australian mammals. Palaeogeogr. Palaeoclimatol. Palaeoecol. 272, 69-84.

Tütken, T., Vennemann, T., 2009. Stable isotope ecology of Miocene large mammals from Sandelzhausen, Germany. Paläeontol. Z. 83, 207-226.

Ungar, P.S., 1996. Dental microwear of European Miocene catarrhines: evidence for diets and tooth use. J. Hum. Evol. 31, 335-366.

van de Weerd, A., Daams, R., 1978. Quantitative composition of rodent faunas in the Spanish Neogene and paleoecological implications. Koninklijke Nederlandse Akademie Van Wetenschappen B 81, 448-473.

Vischer, N.O.E., Huls, P.G., Woldringh, C.L., 1994. Object-Image: an interactive image analysis program using structured point collection. Binary 6, 160-166.

Walker, A., Hoeck, H.N., Perez, L., 1978. Microwear of mammalian teeth as an indicator of diet. Science 201, 908-910.

Wegge, P., Shrestha, A.K., Moe, S.R., 2006. Dry season diets of sympatric ungulates in lowland Nepal: competition and facilitation in alluvial tall grasslands. Ecol. Res. 21, 698-706.

Williams, S.E., Marsh, H., 1998. Changes in small mammal assemblage structure across a rain forest/open forest ecotone. J. Trop. Ecol. 14, 187-198.

Williams, S.E., Marsh, H., Winter, J., 2002. Spatial scale, species diversity, and habitat structure: small mammals in Australian tropical rain forest. Ecology 83. 1317-1329.

You, Y., Huber, M., Muller, R.D., Poulsen, C.J., Ribbe, J., 2009. Simulation of the middle Miocene climate Optimum. Geophys. Res. Lett. 36. doi:10.1029/ 2008GL036571

Zapfe, H., 1960. Die Primatenfunde aus der miozänen Spaltenfüllung von Neudorf an der March (Devínska Nova Ves), Tschechoslowakei. Schweizerische Paläontologische Geselschaft, Abhandlungen 78, 1-293.

Ziegler, R., Falbusch, V., 1986. Kleinsäuger-Faunen aus der basalen Oberen Süßwasser-Molasse Niederbayerns. Zitteliana 14, 3-80. 